\title{
IEA: memória fotográfica
}

\begin{abstract}
A s 38 fotos que se seguem apresentam ao leitor de ESTUDOS A avançados uma reduzida amostra das atividades do IEA e das pessoas que delas participaram nesses primeiros 25 anos do Instituto.

Estão aí representados professores e pesquisadores visitantes, professores honorários, conferencistas e debatedores convidados, projetos e eventos acadêmicos, com a participação de integrantes da USP, de outras universidades e instituições de pesquisa, brasileiras e estrangeiras. A partir de um acervo de milhares de fotos, que registram a atuação de mais de dois mil pesquisadores, teve-se de assumir o constrangimento de inúmeras omissões. Só nos resta render a devida homenagem também a todos os ausentes desta seleção. (Mauro Bellesa)
\end{abstract}




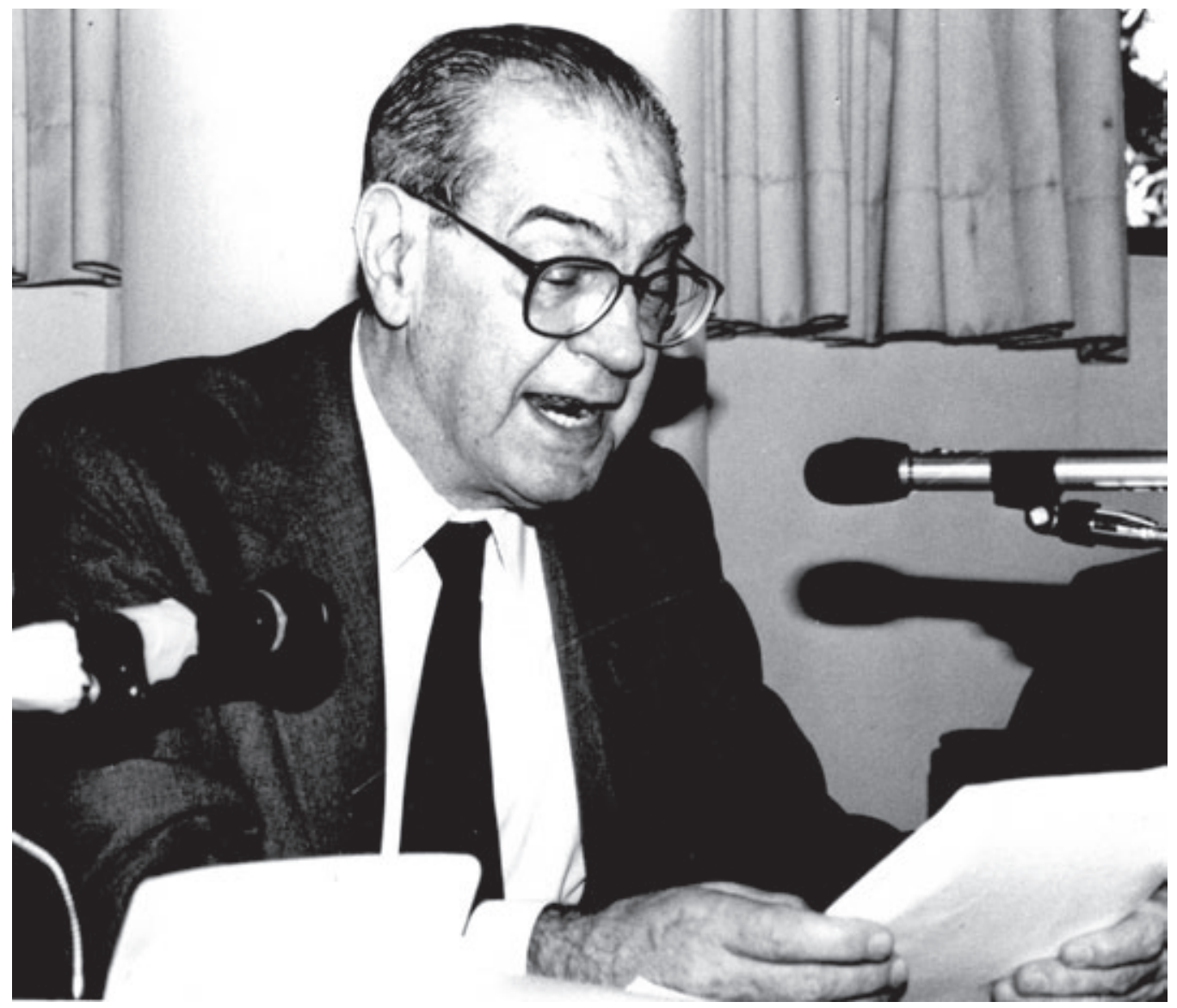

Raymundo Faoro (1925-2003) foi o primeiro conferencista e o primeiro professor visitante, em 1986; na foto (de 1992), profere sua $2^{a}$ conferência no Instituto.

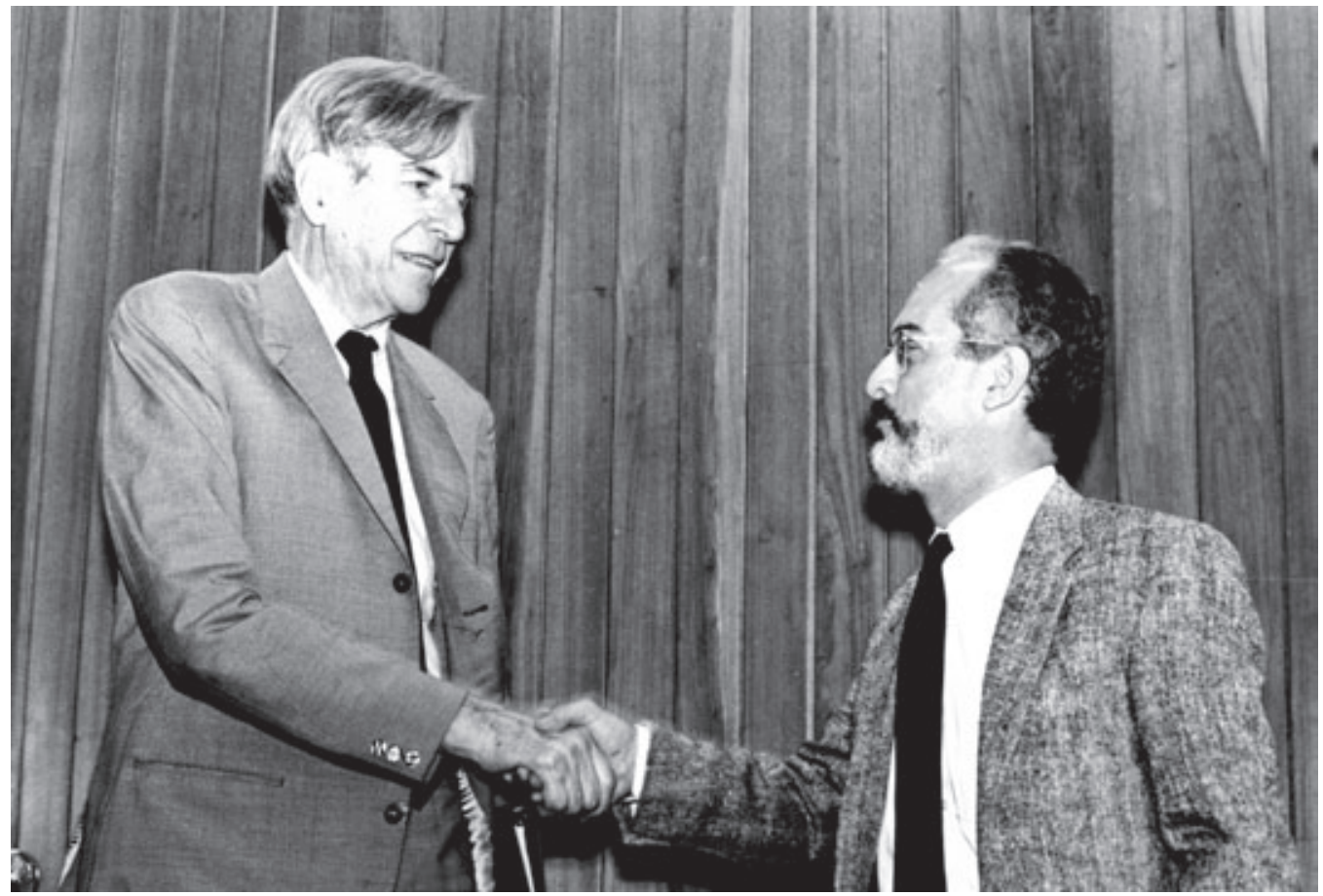

John Kenneth Galbraith (1908-2006), conferencista convidado, e o então diretor arlos Guilherme Mota em evento de 1987. 


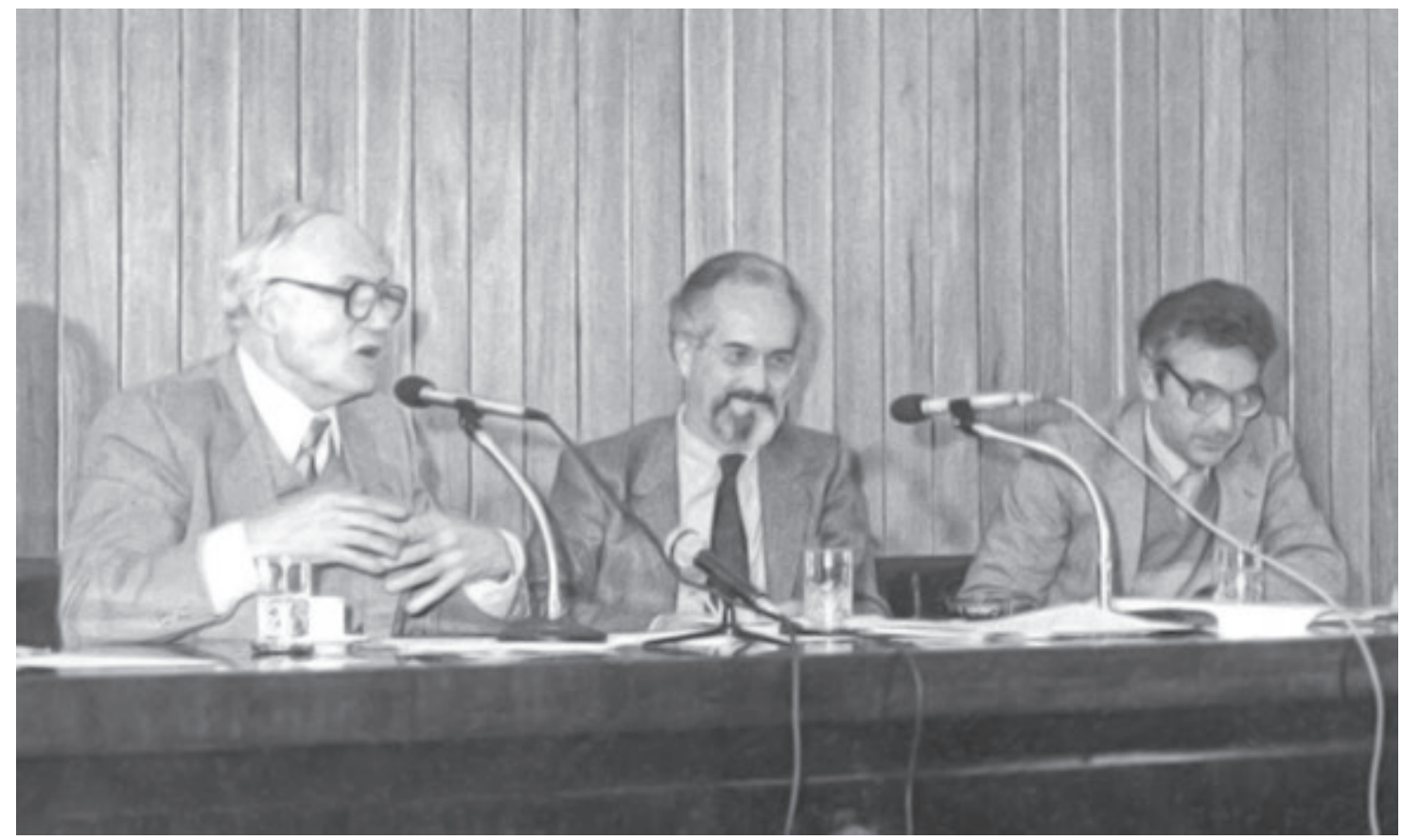

Richard Morse (1922-2001), à esq. na foto, durante conferência em 1987, tendo ao lado Carlos Guilherme Mota e Alfredo Bosi.

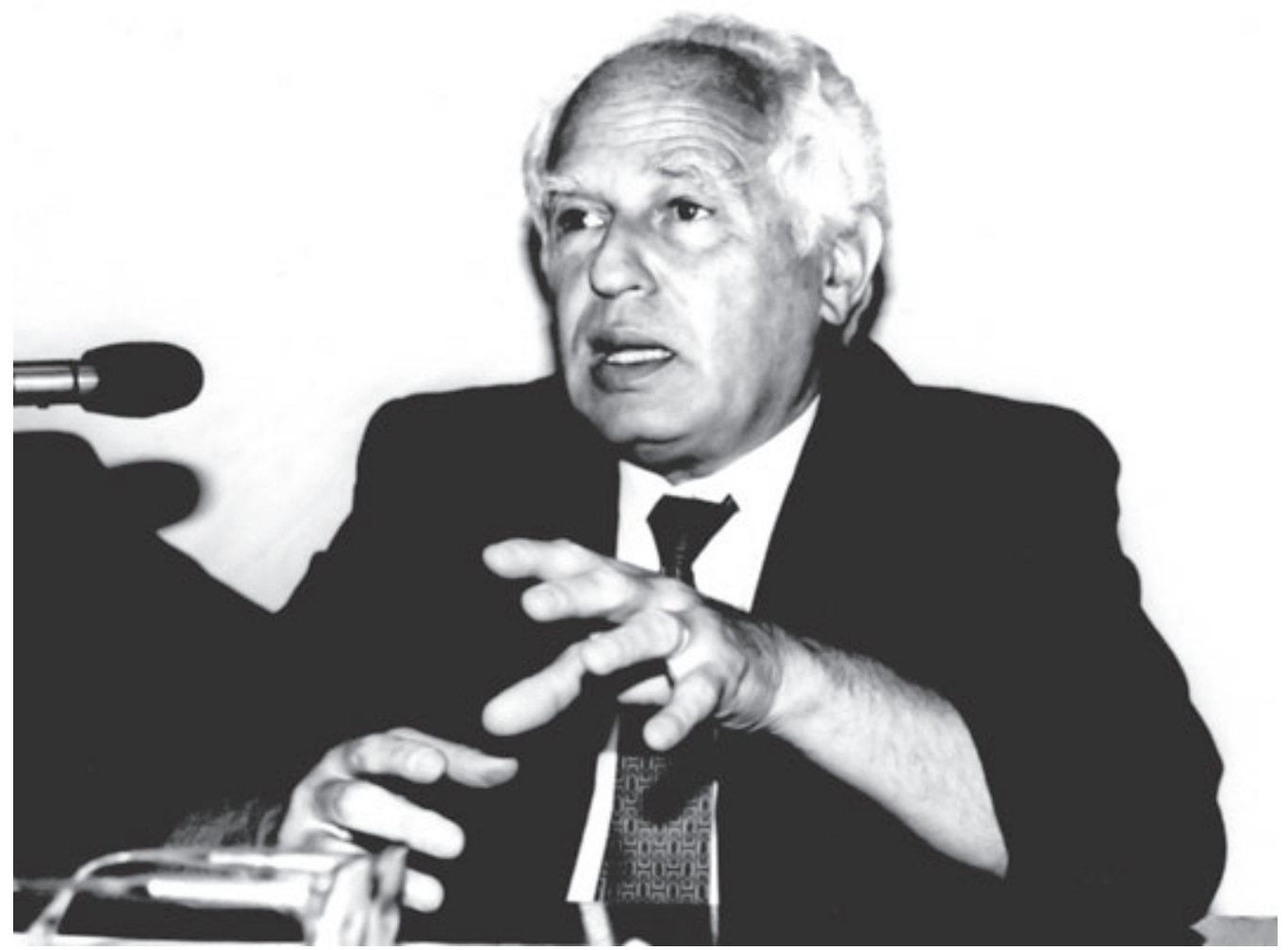

José Goldemberg, reitor quando da criação do IEA, professor honorário e colaborador em diversas atividades. 


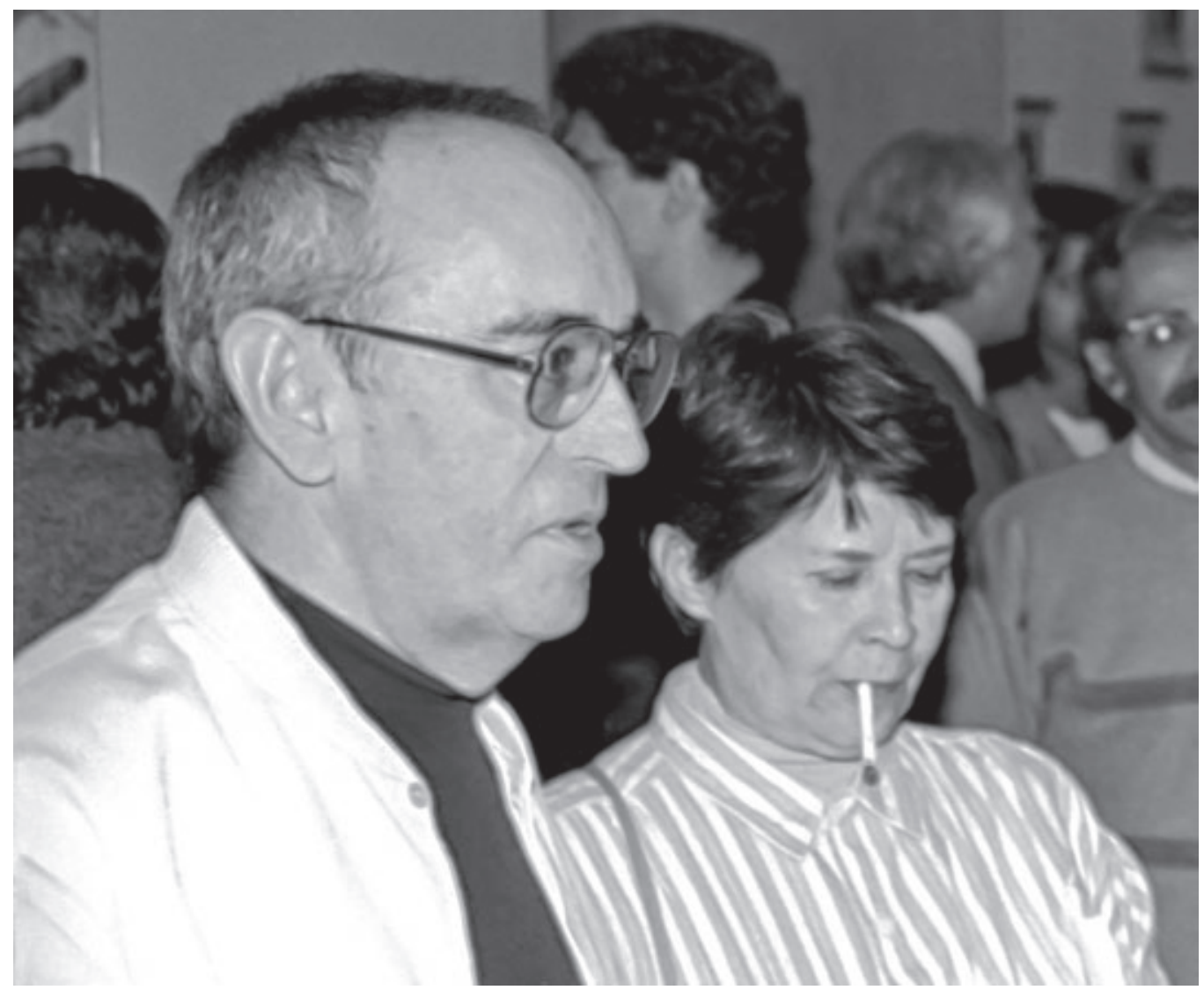

José Paulo Paes (1926-1998), um dos primeiros professores visitantes, com sua mulher, Dora, em evento no Instituto.

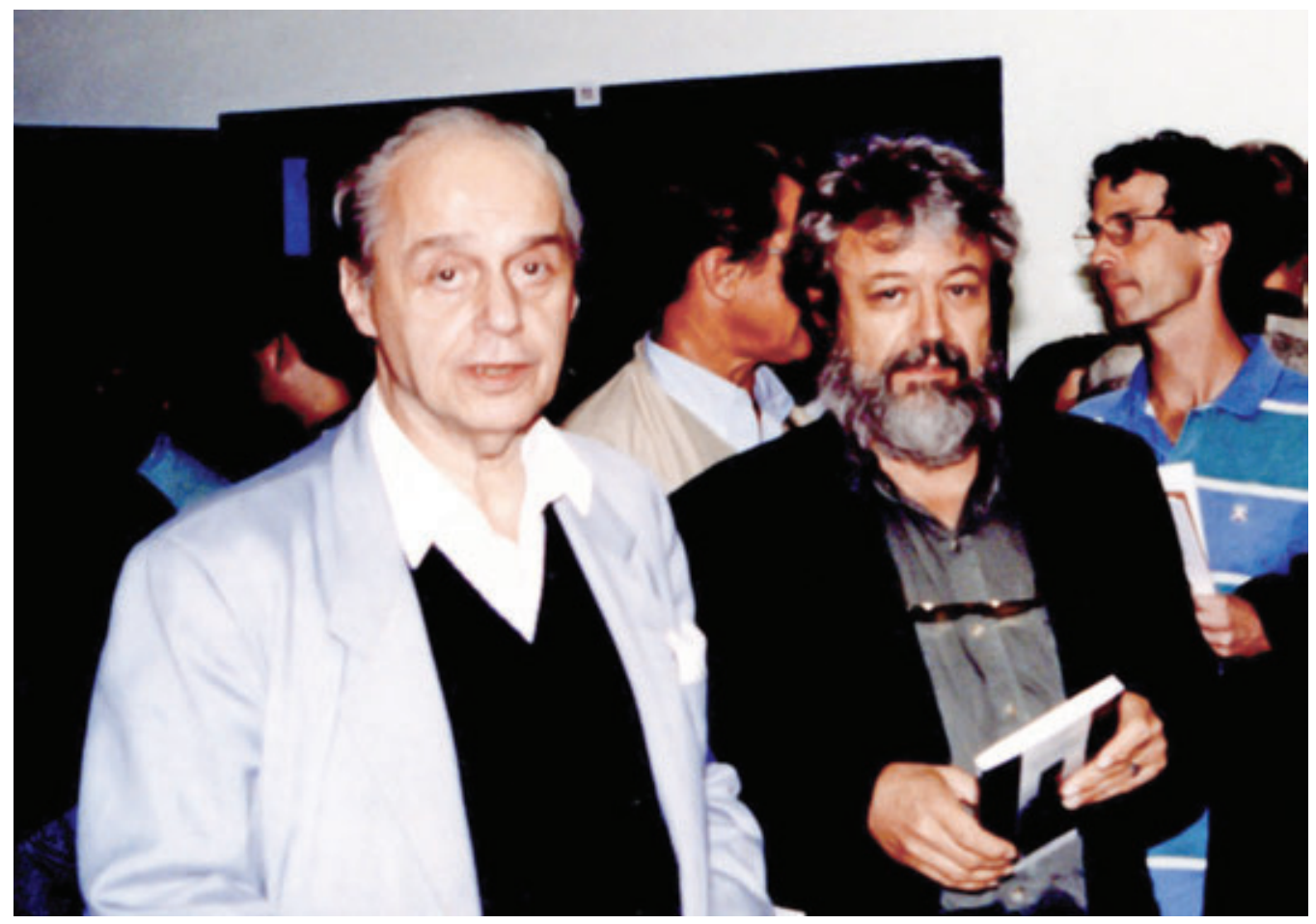

Alberto Luiz da Rocha Barros, um dos entusiastas da criação do IEA, e Michel Paty, participante frequente na vida do Instituto. 


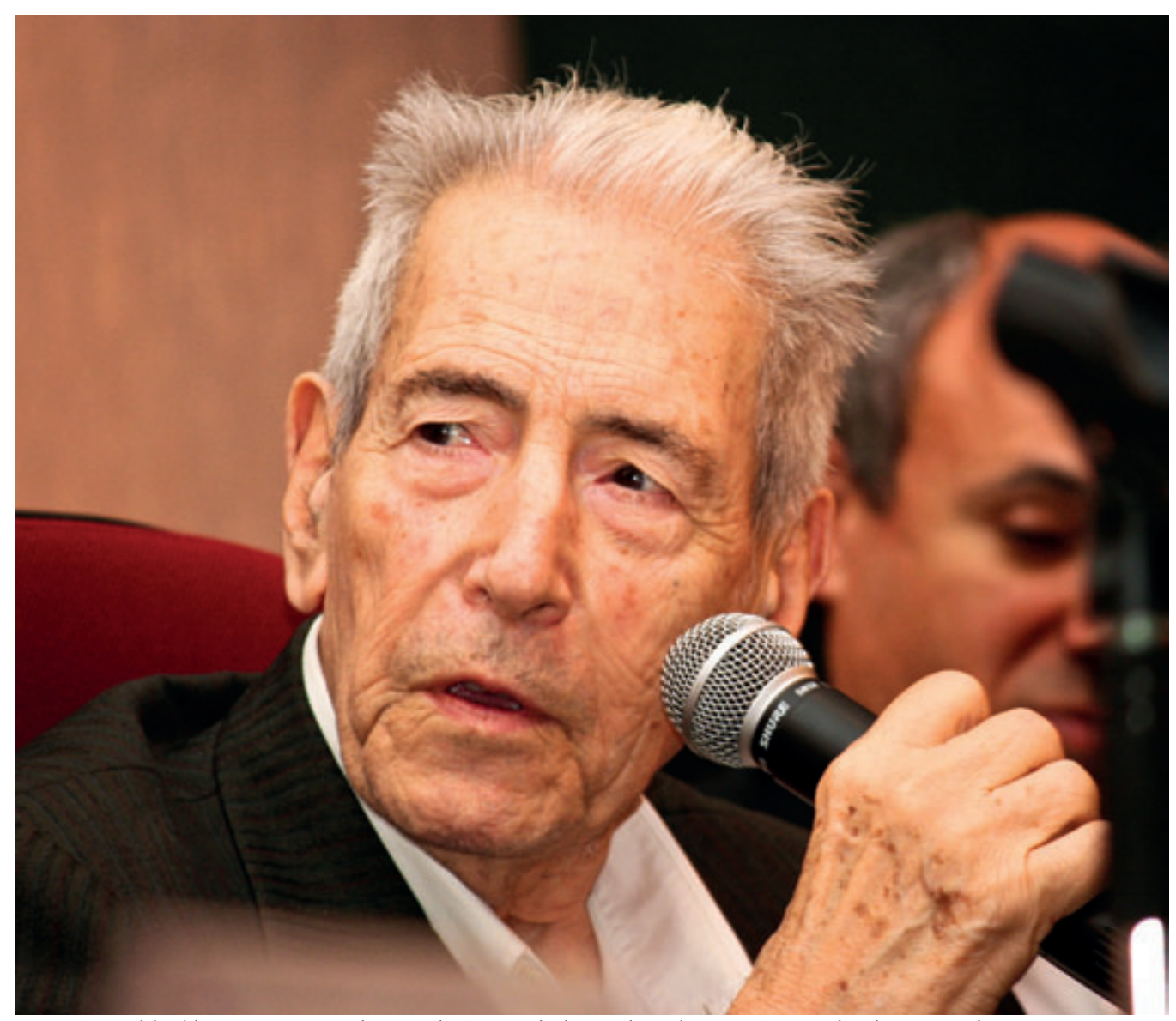

Aziz Ab'Sáber, professor honorário e colaborador do Instituto desde o final dos anos de 1980.

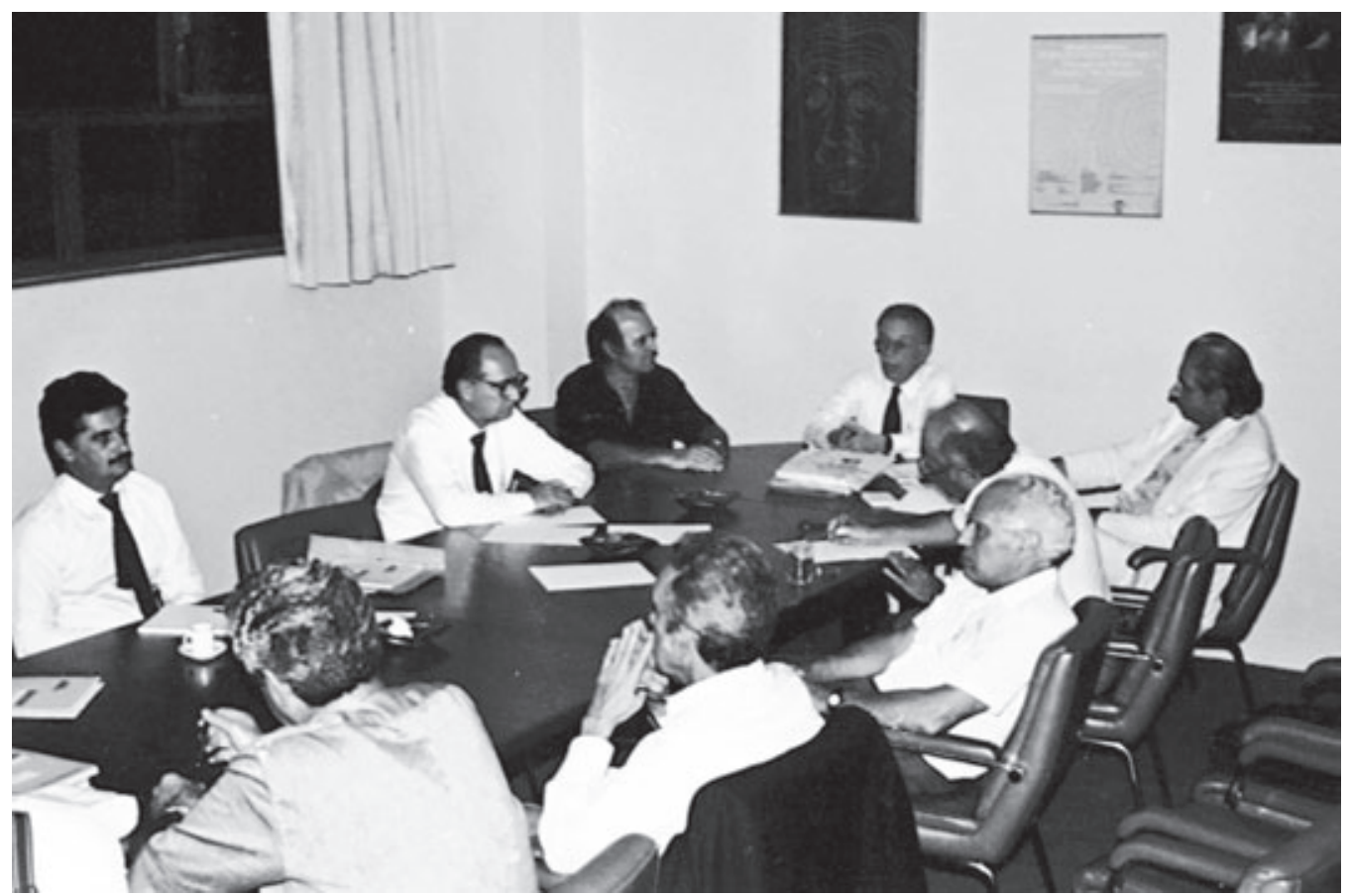

Reunião de trabalho dos autores do Projeto Floram em 1990. 


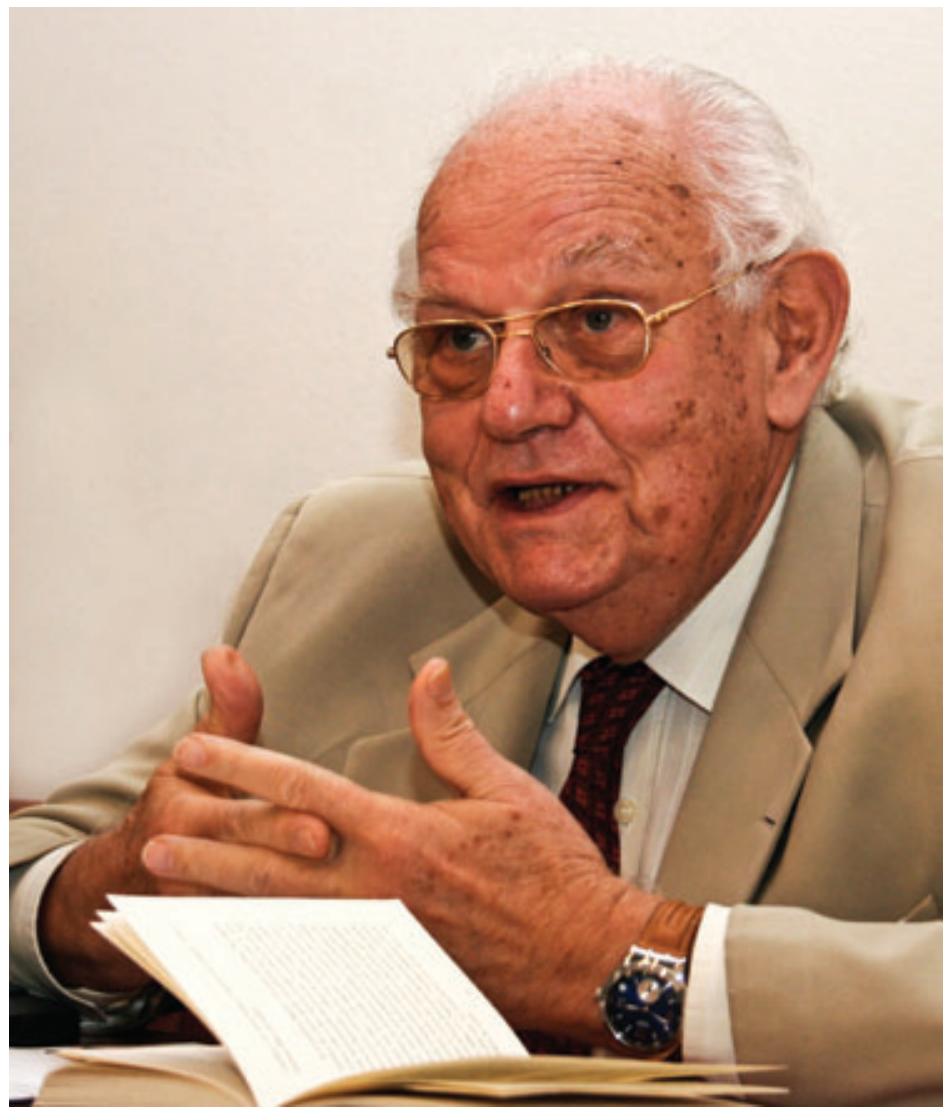

Ignacy Sachs, pesquisador visitante com participação constante nas atividades do Instituto desde 1989.

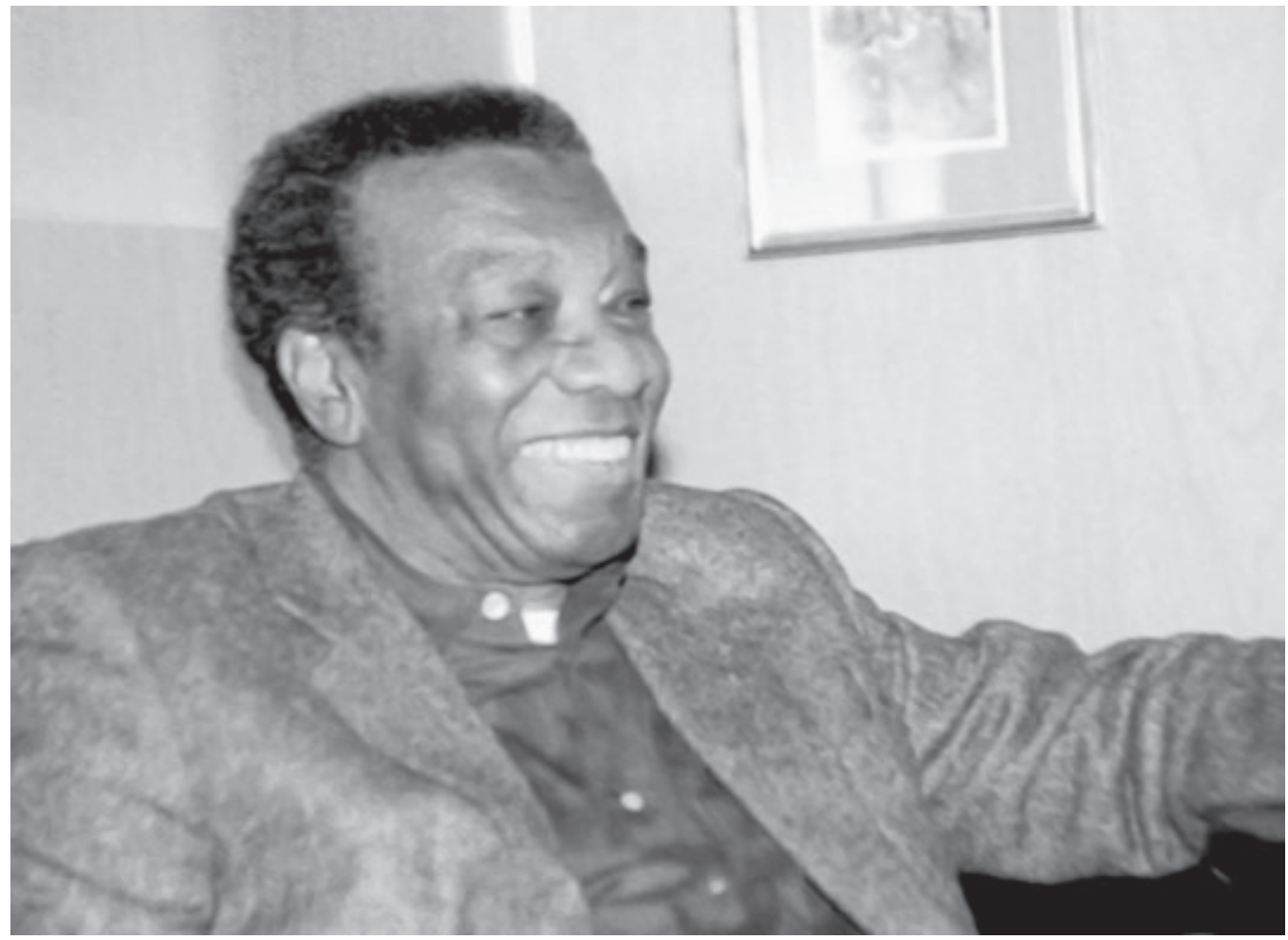

Milton Santos no IEA no início dos anos de 1990. 


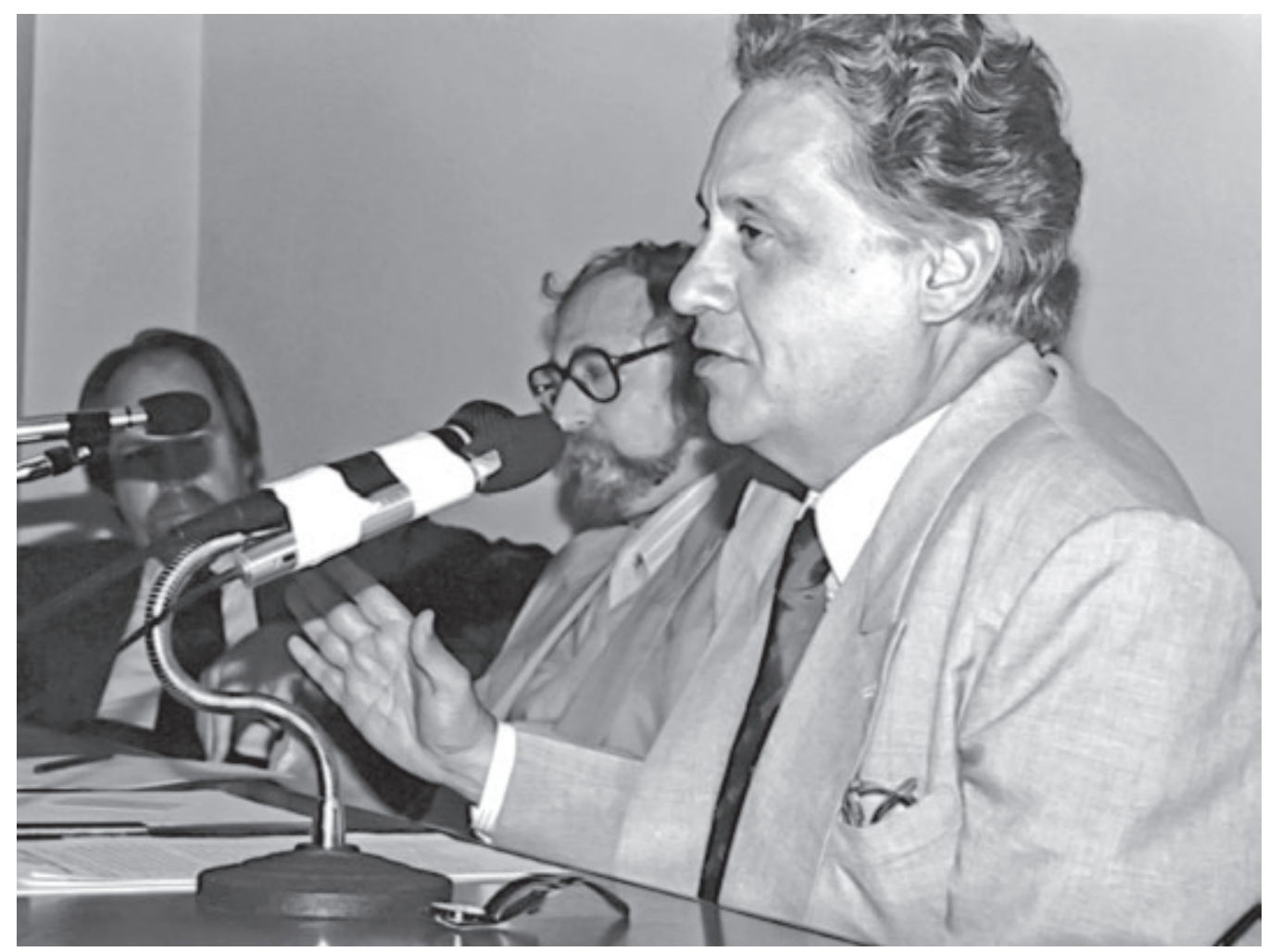

Em 1991, o então senador Fernando Henrique Cardoso participou do ciclo

"Presidencialismo versus Parlamentarismo".
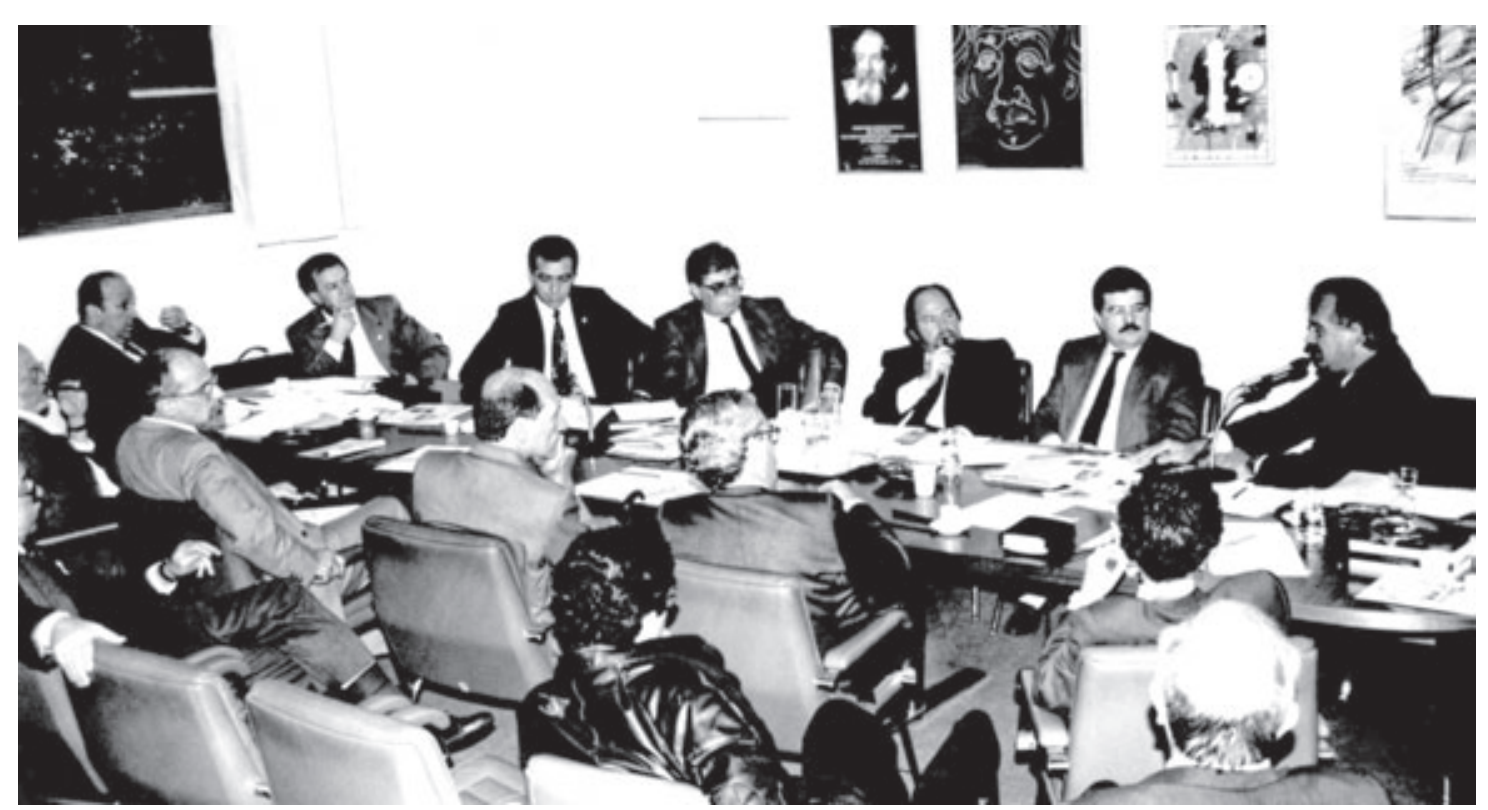

Reunião em 1991 dos integrantes do Projeto Mercosul, coordenado pelo professor visitante Ricardo Seitenfus (falando ao microfone à dir.). 


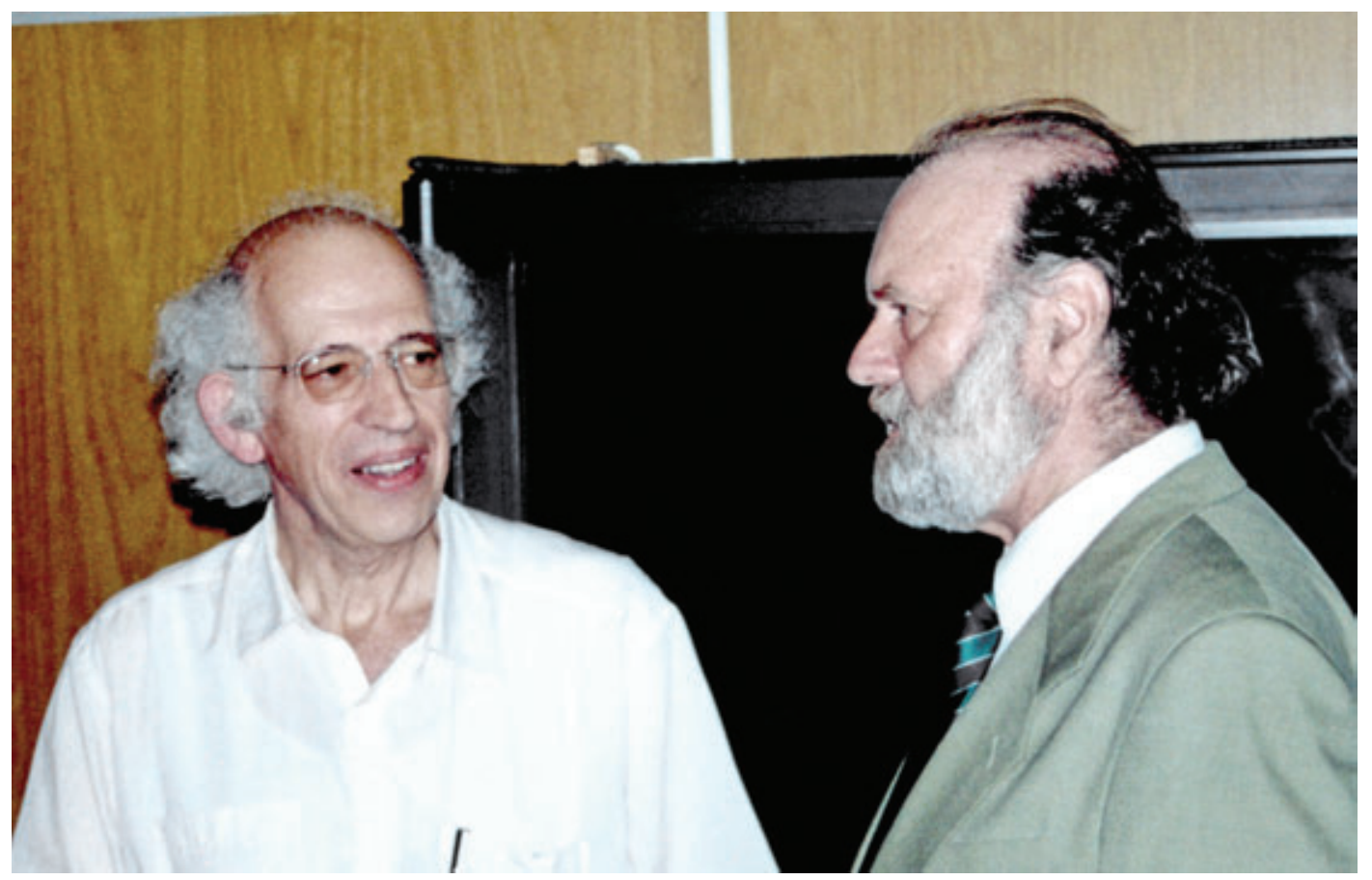

Imre Simon (1943-2009), que foi conselheiro e coordenador de grupo de pesquisa, com Umberto Cordani, ex-diretor do Instituto.

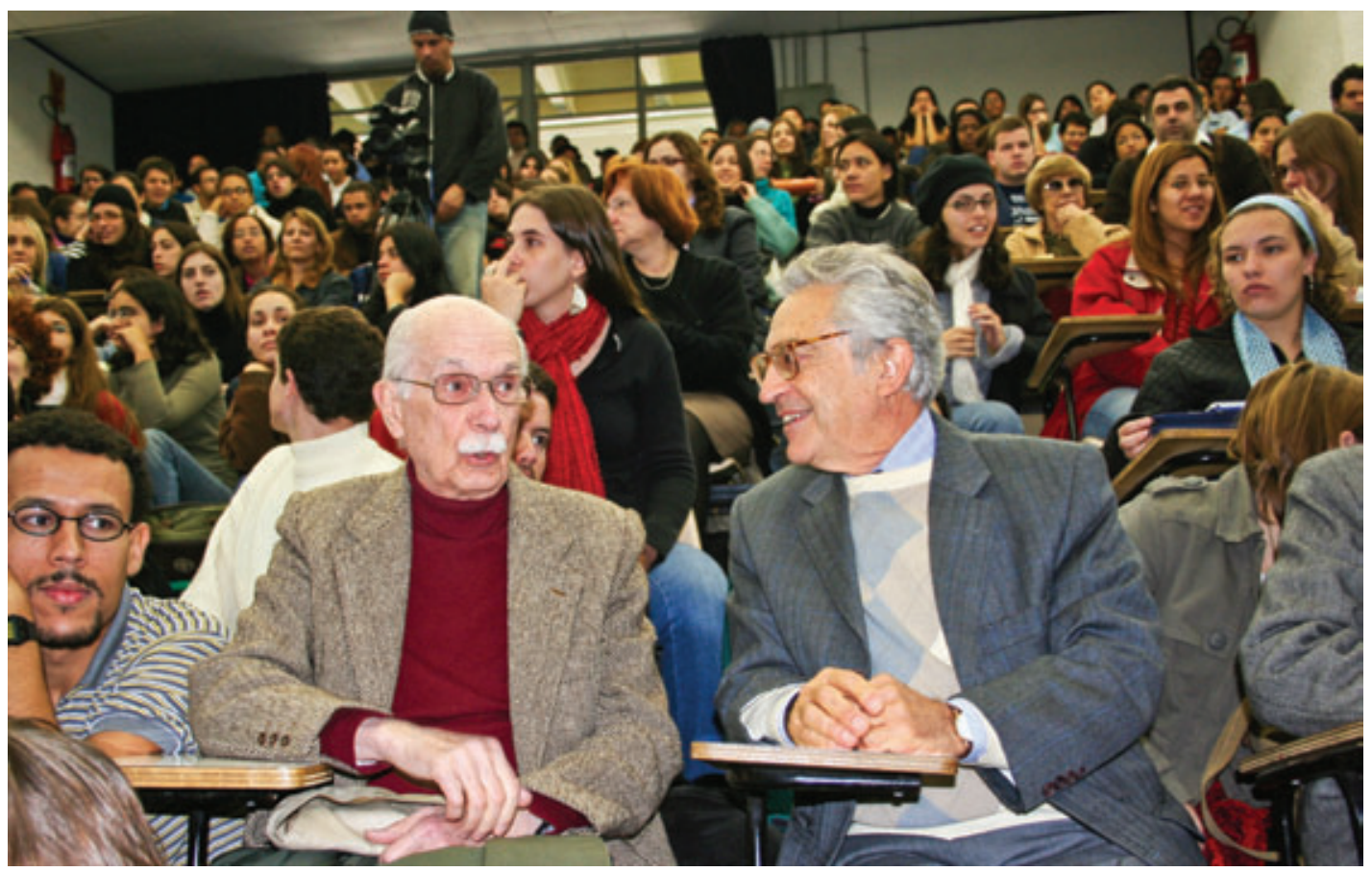

Antonio Candido, professor honórario e assíduo colaborador, com Alfredo Bosi, ex-diretor do Instituto e editor da revista ESTUDOS AVANCSADOS. 


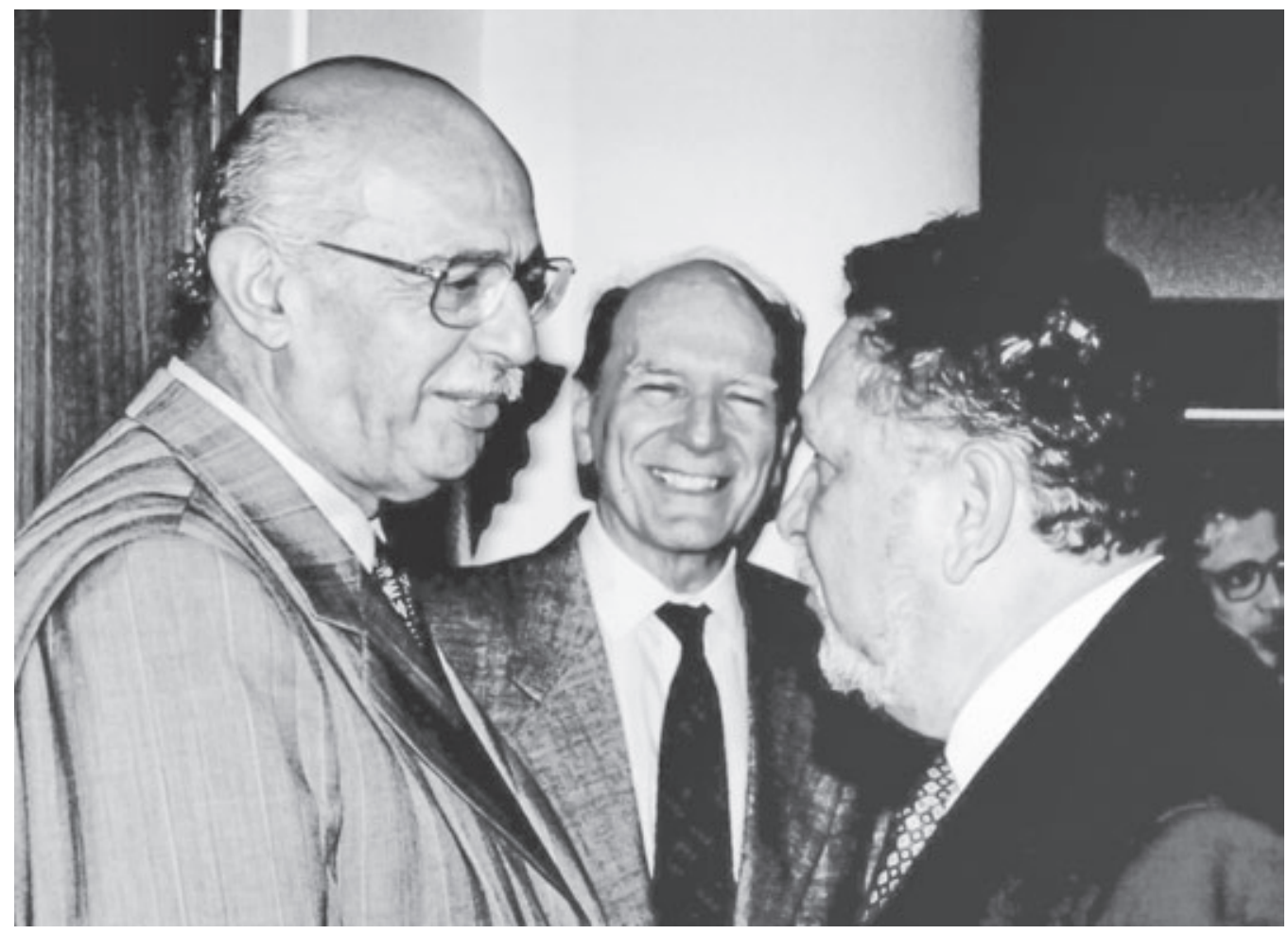

Adib Jatene, Gehard Malnic (ex-diretor) e José Galizia Tundisi em encontro no final da década de 90.

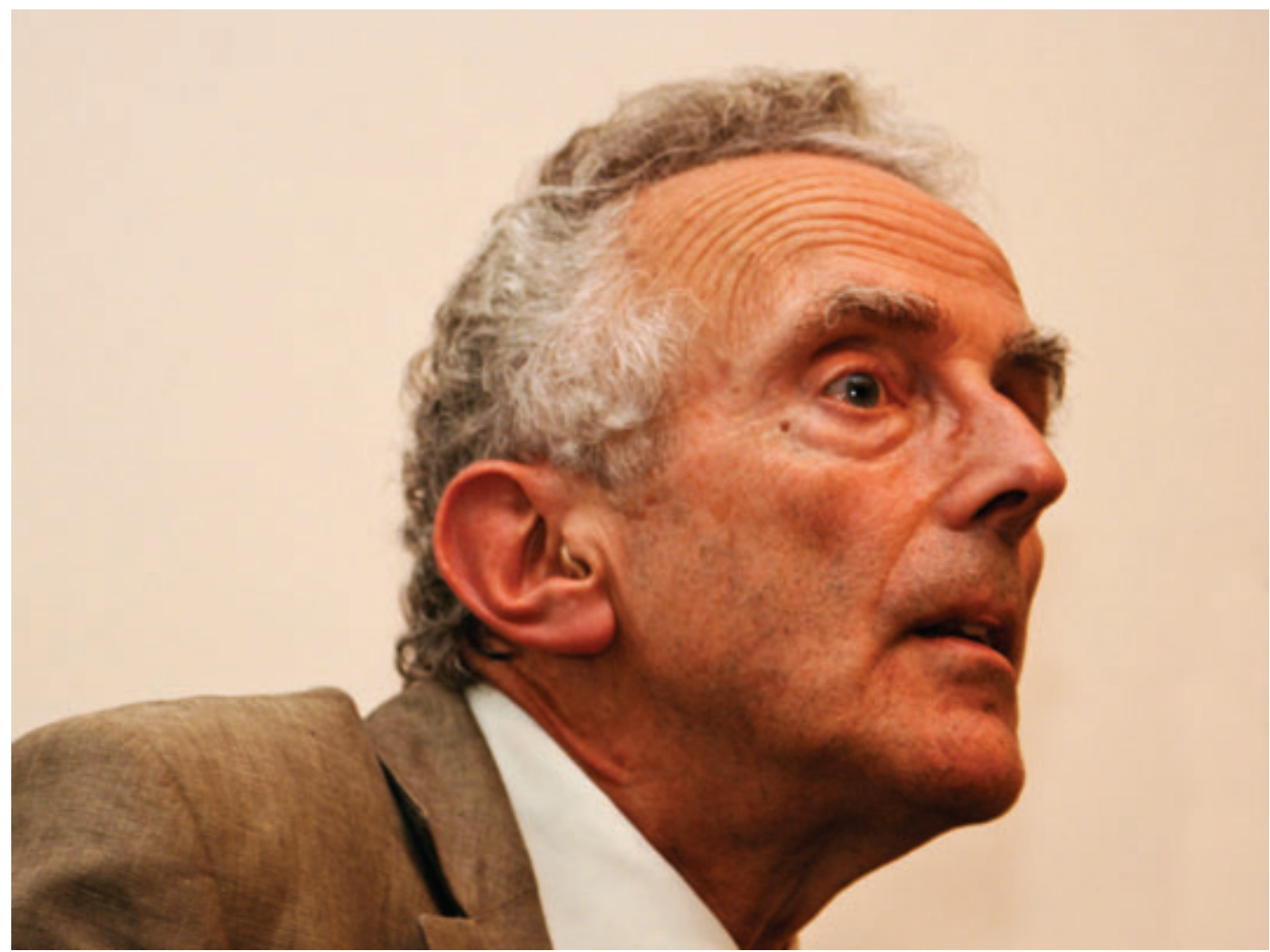

Peter Burke foi professor visitante nos anos de 1990 e conferencista convidado em outras ocasiões. 


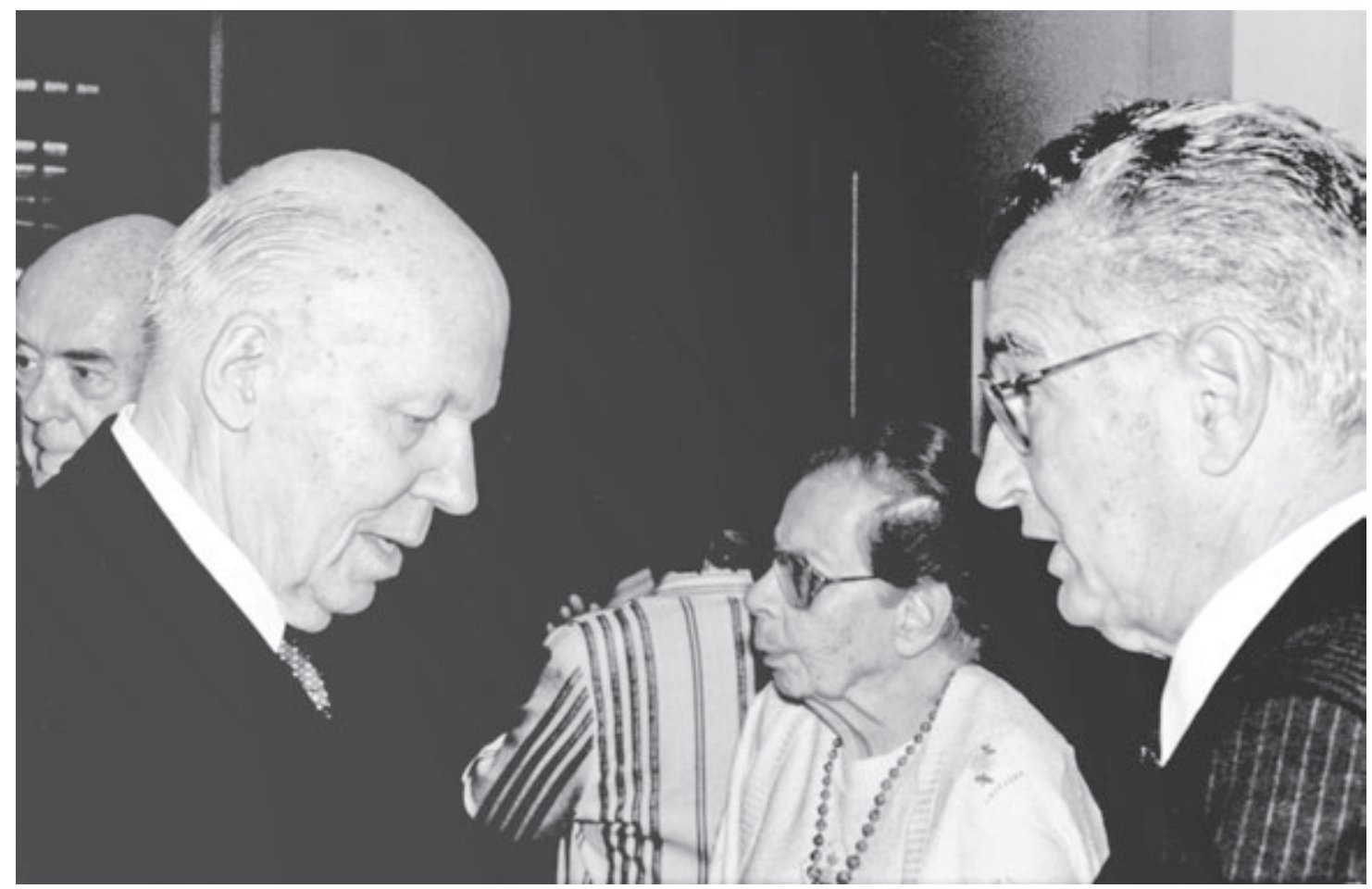

Paschoal Senise (1917-2011) e Crodowaldo Pavan (1919-2009), professores honorários do IEA.

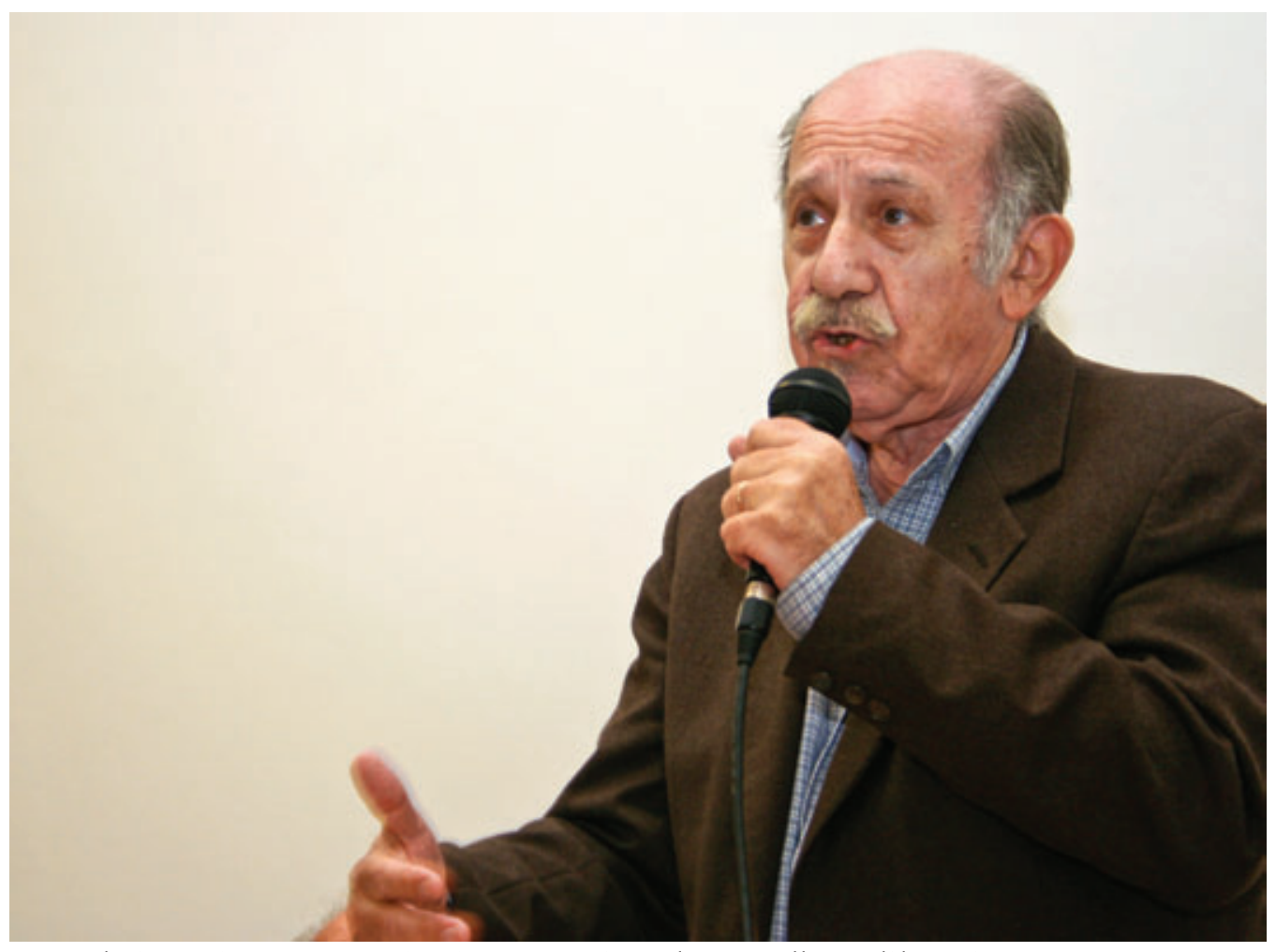

Paul Singer integrou a primeira composição do Conselho Deliberativo, tendo participado como conferencista e debatedor em diversos eventos. 


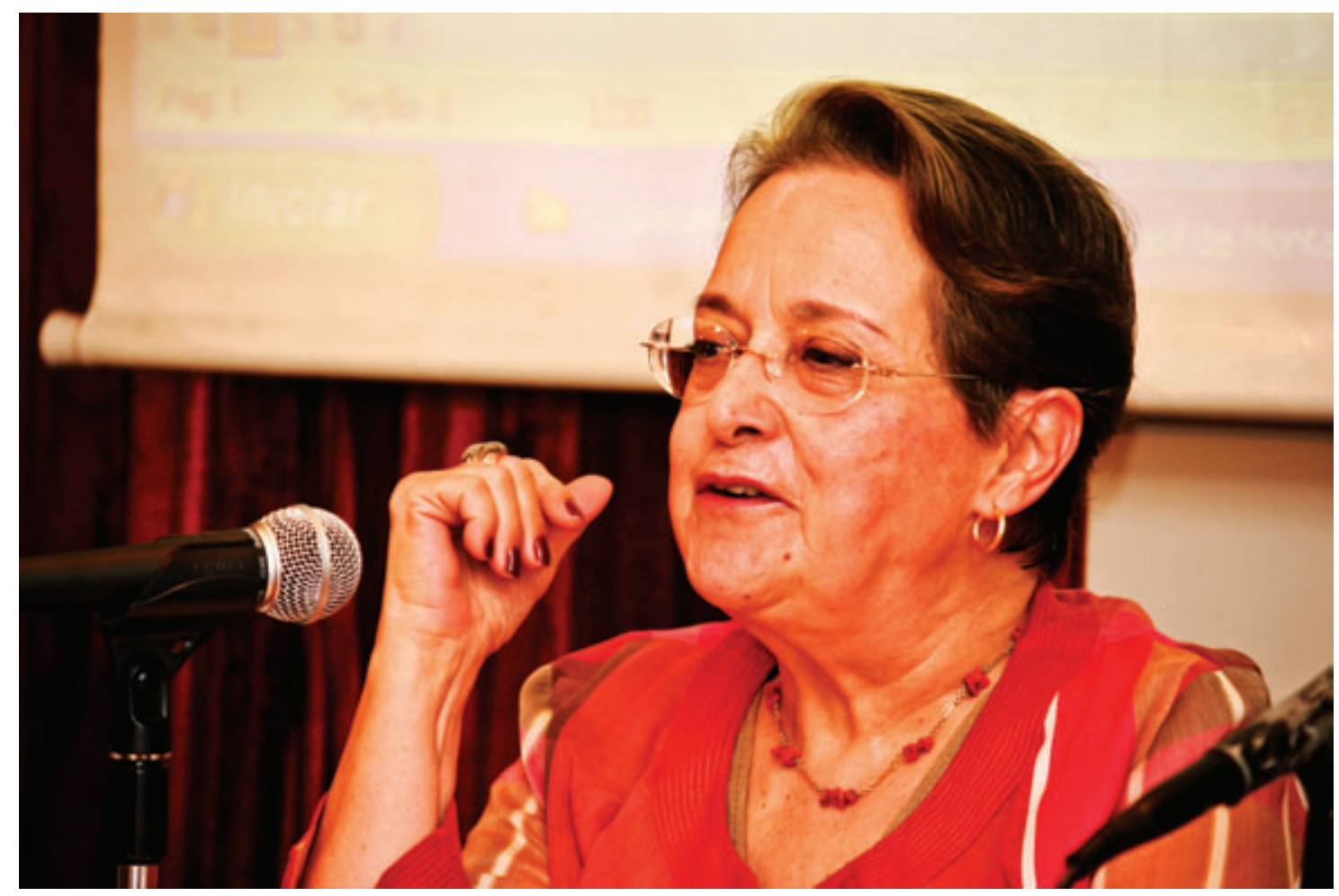

Leyla Perrone-Moisés, criadora do Núcleo de Pesquisa Brasil-França.

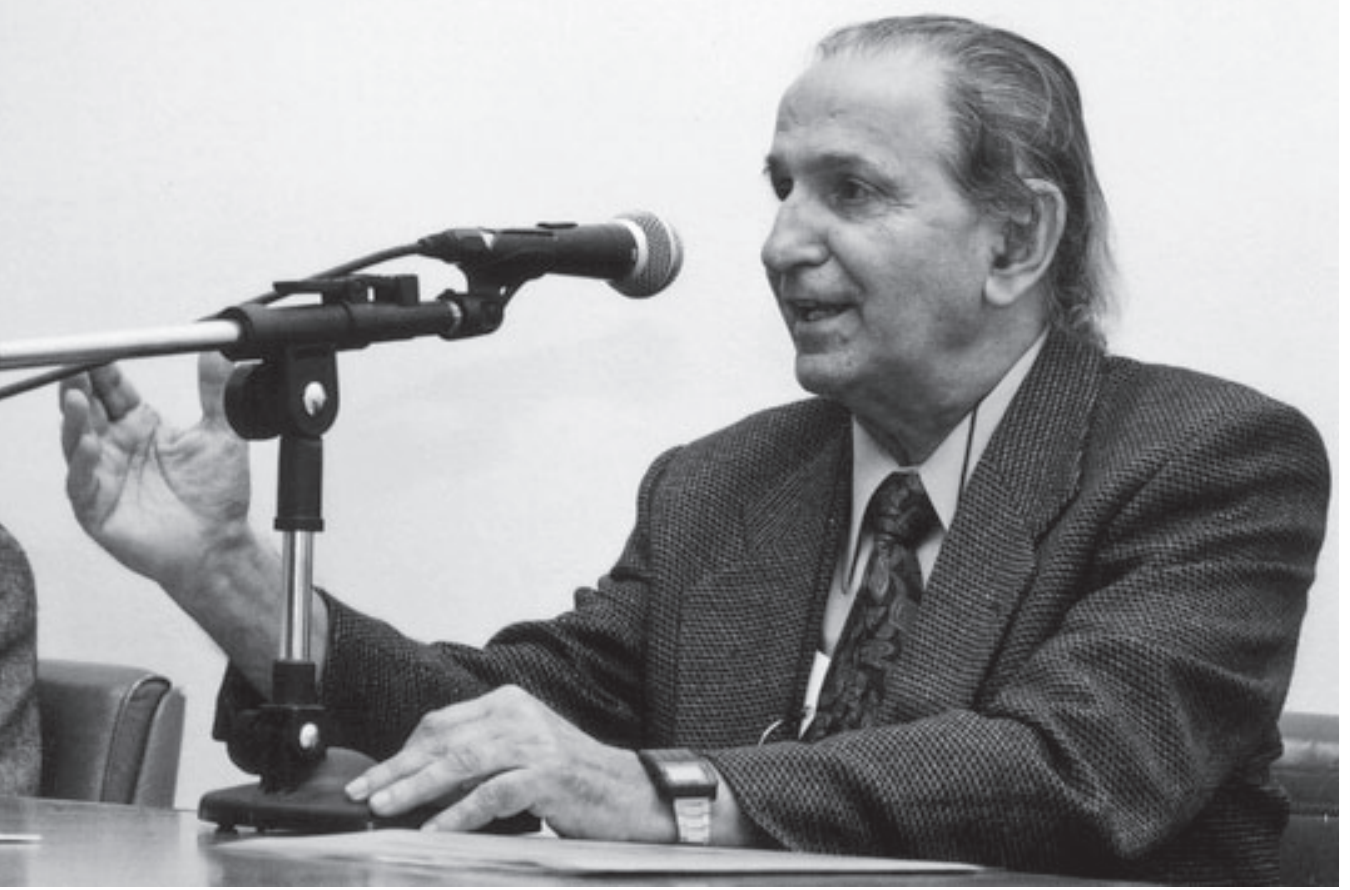

Sérgio Mascarenhas, professor honorário do IEA e criador do Polo São Carlos do Instituto. 


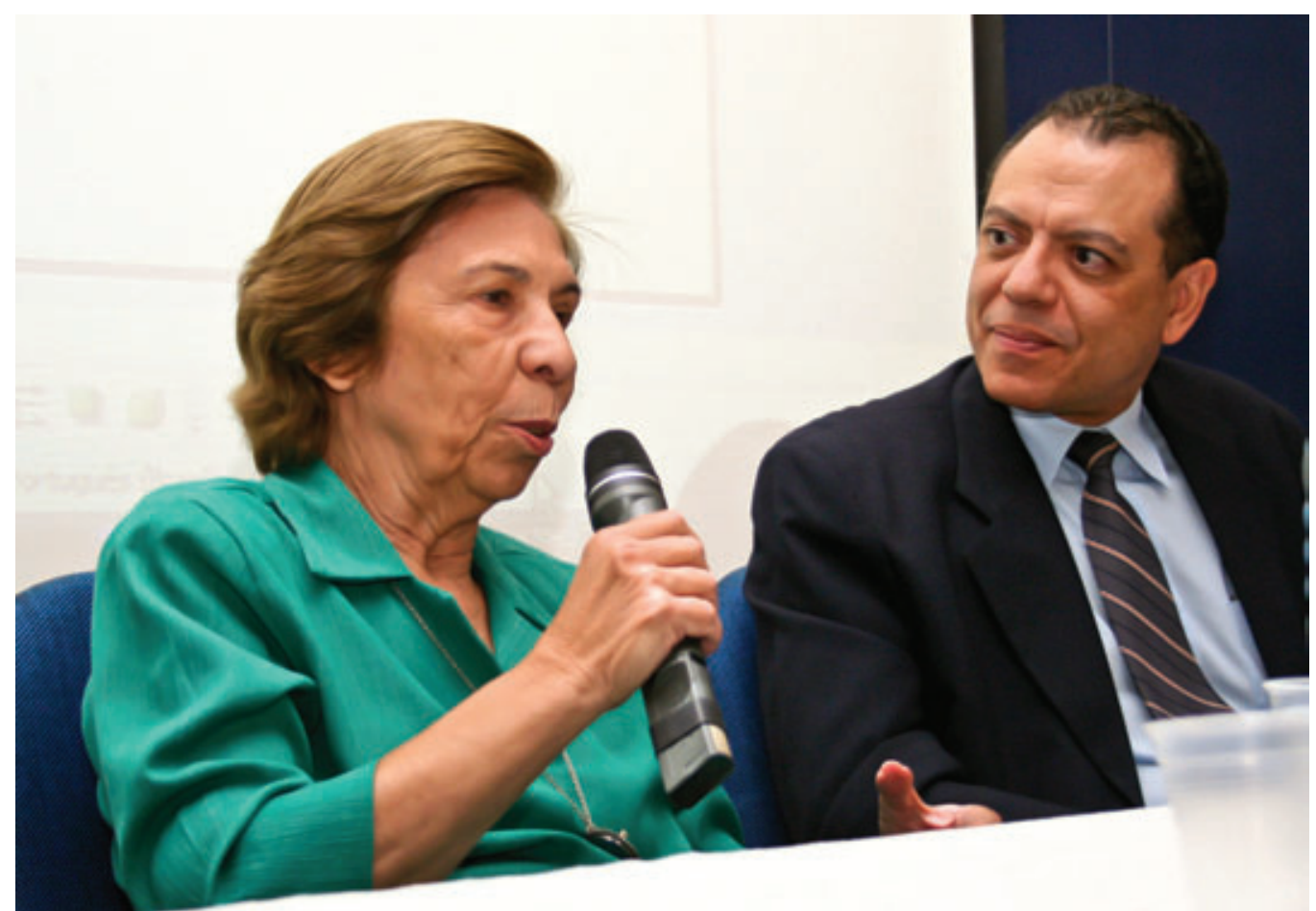

Yvonne Mascarenhas, professora honorária e ex-conselheira, com Glancius Oliva, atual presidente do CNPq, em evento no Polo São Carlos do Instituto.

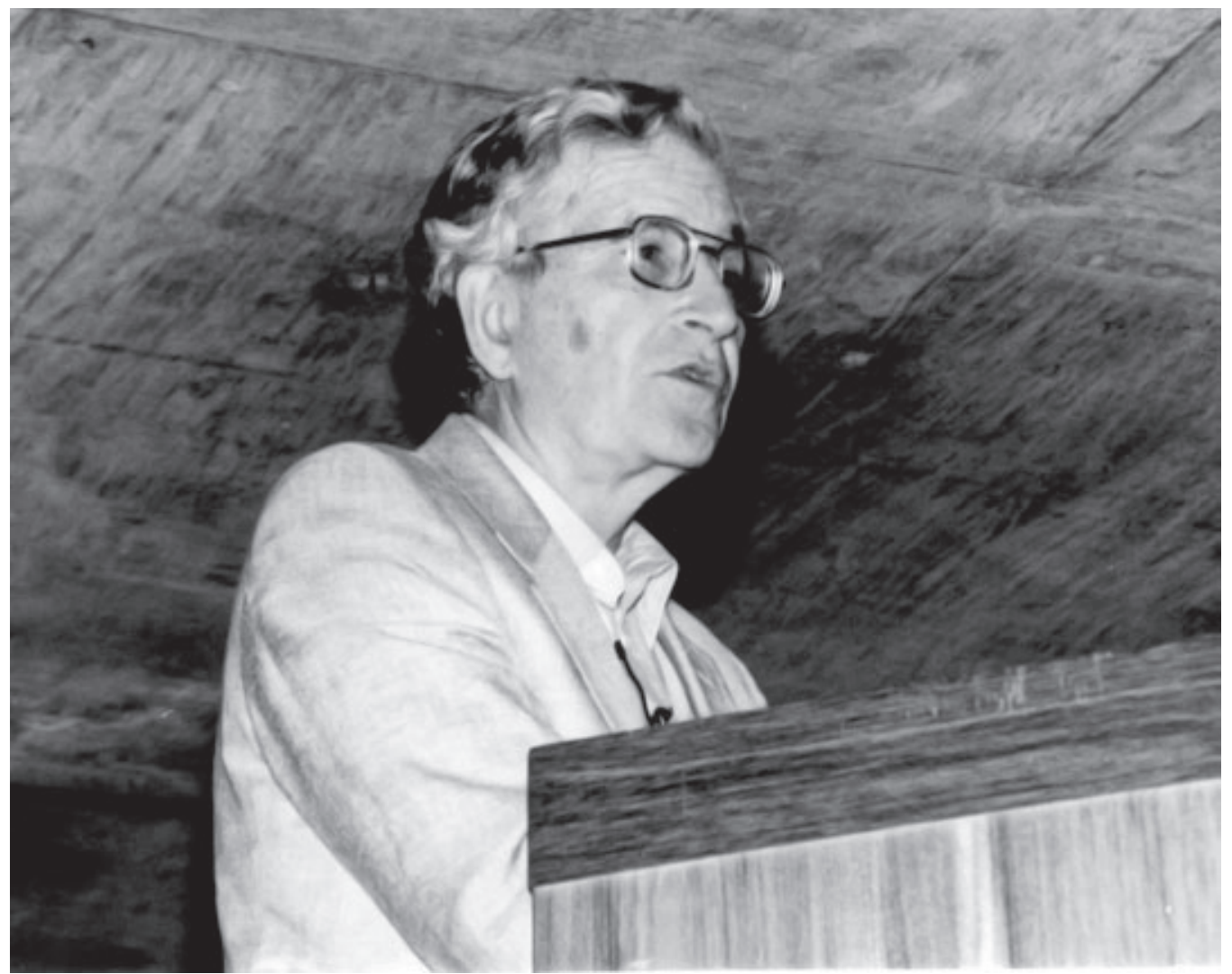

Noam Chomsky foi um dos conferencistas nas comemorações dos 10 anos do IEA, em 1996. 


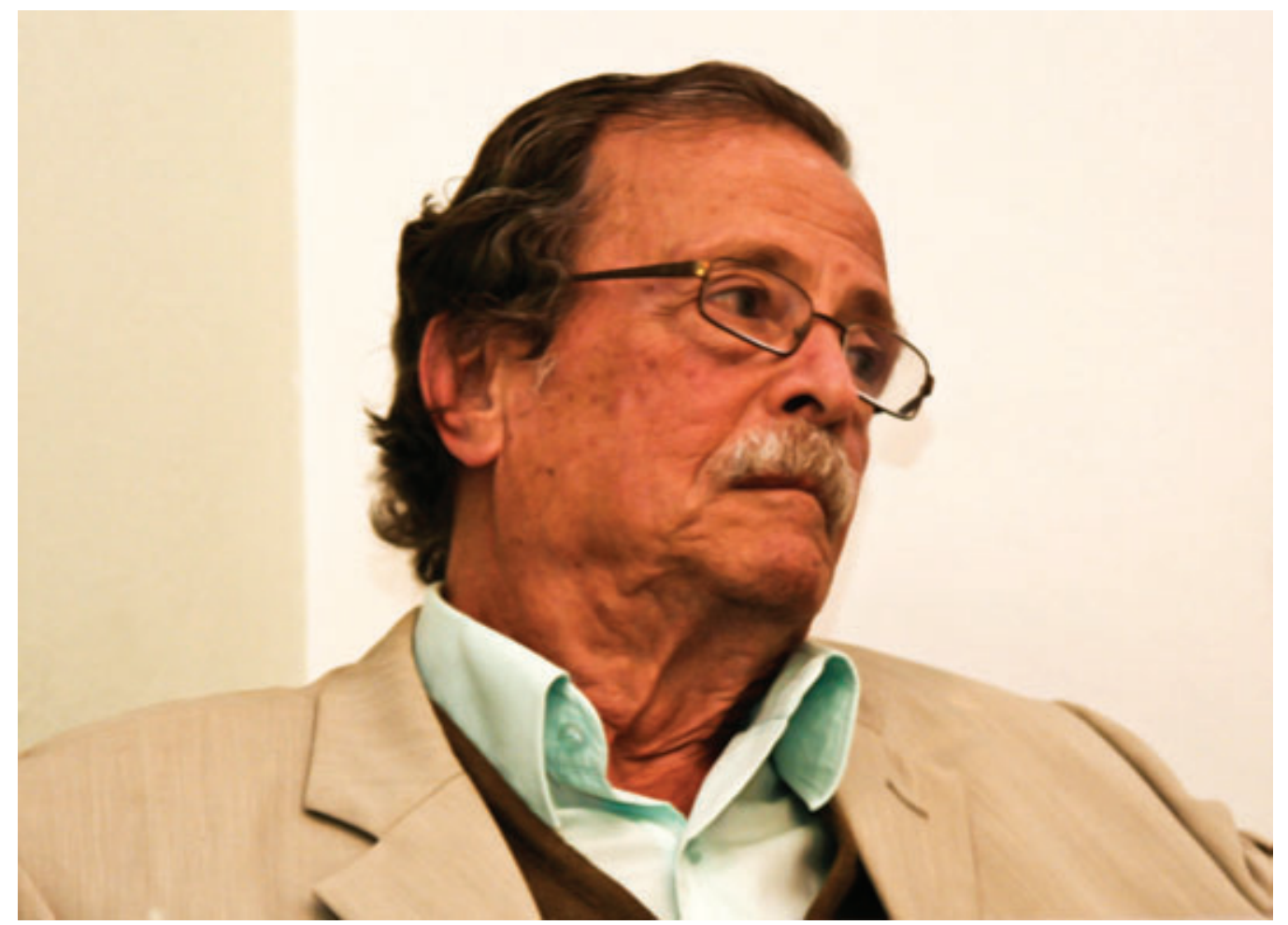

Luiz Hildebrando Pereira Silva tem contribuido de forma significativa em debates e na revista ESTUDOS AVANCADOS.

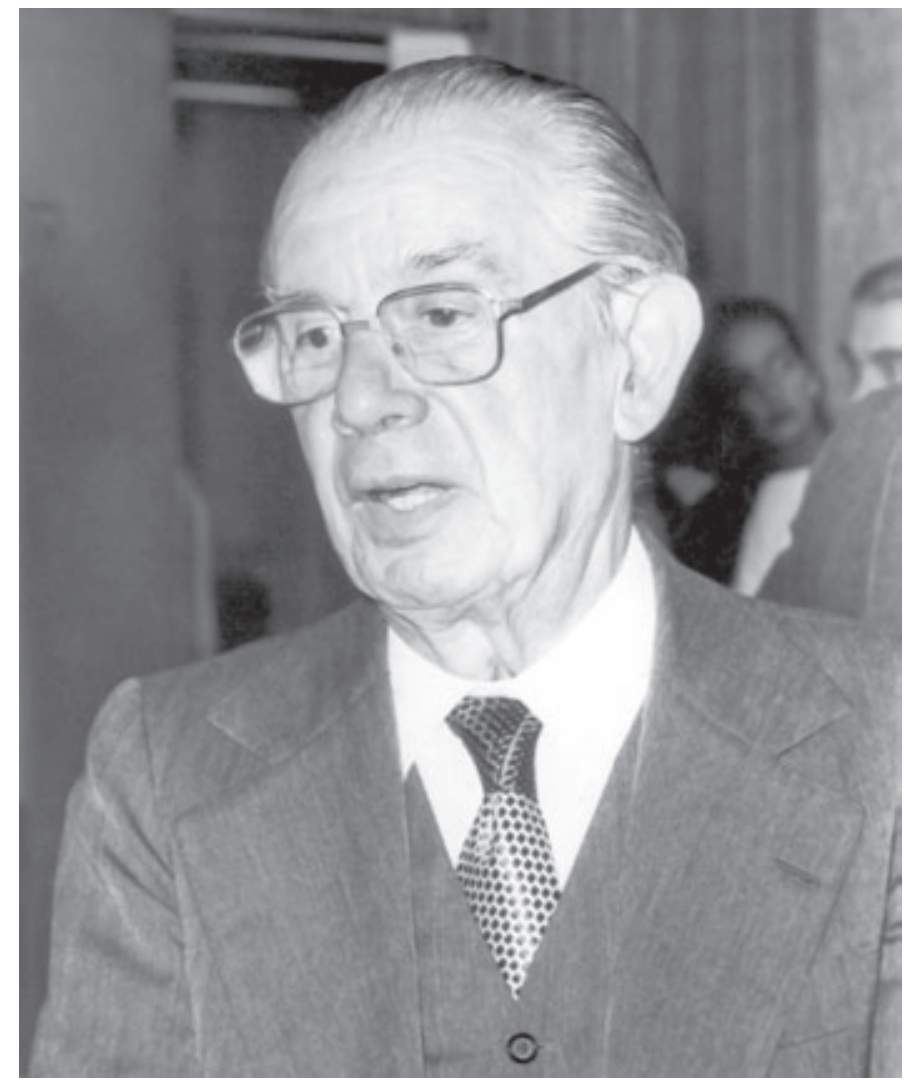

Alberto Carvalho da Silva (1916-2002), professor honorário. 


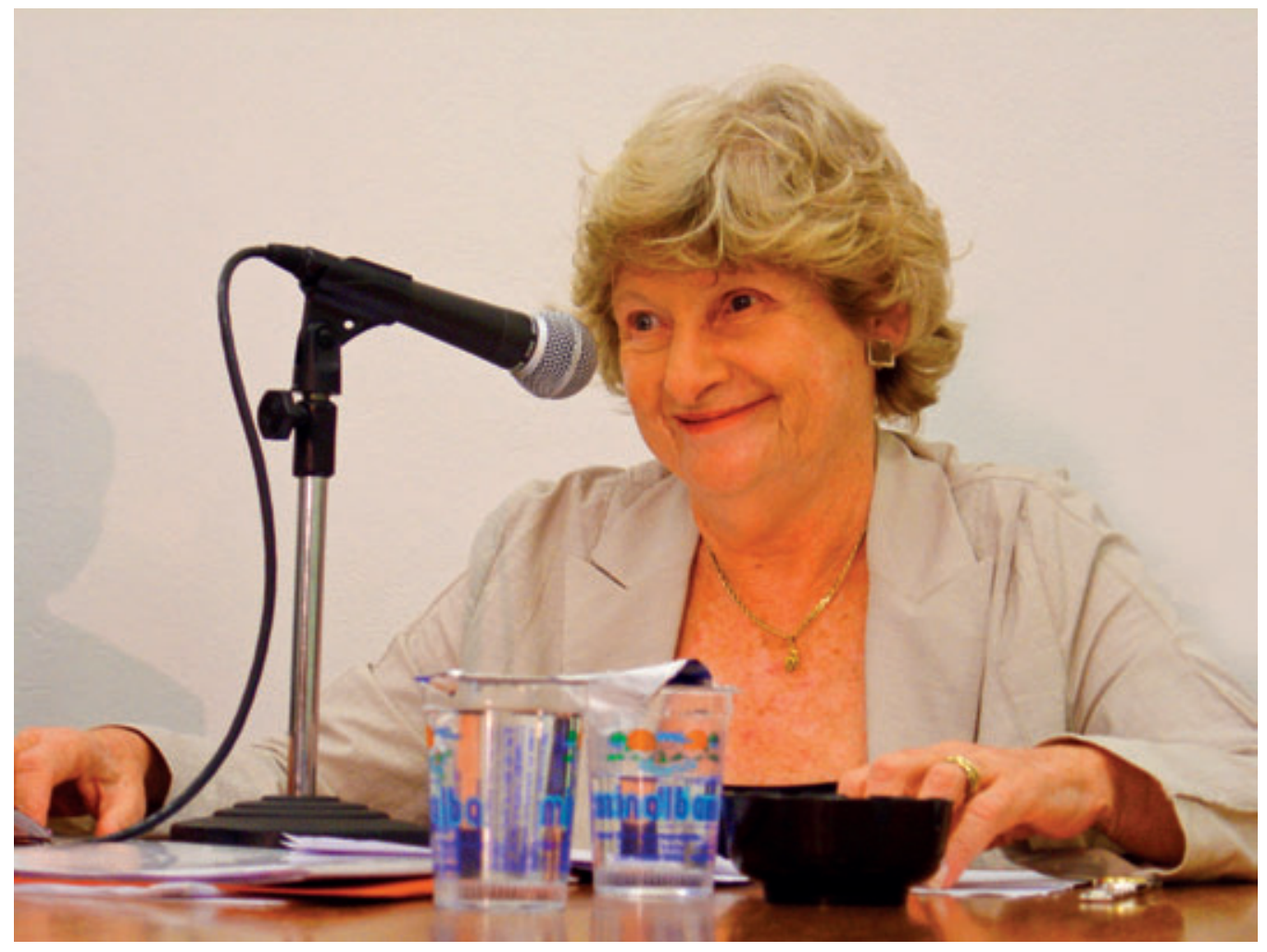

Bertha Becker tem participado com regularidade de seminários sobre a Amazônia.

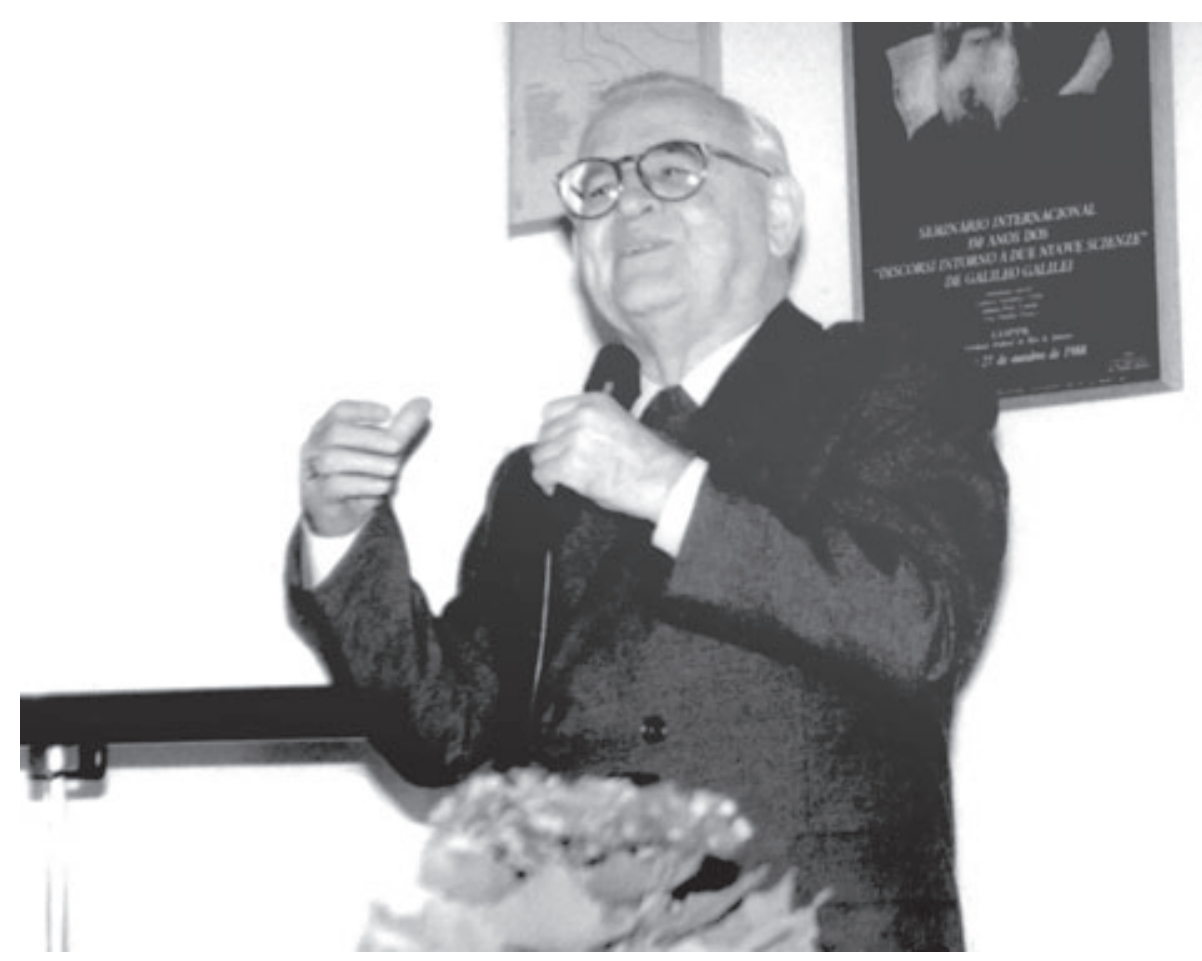

Dom Paulo Evaristo Arns fez parte do Conselho Deliberativo e foi conferencista convidado do Instituto. 


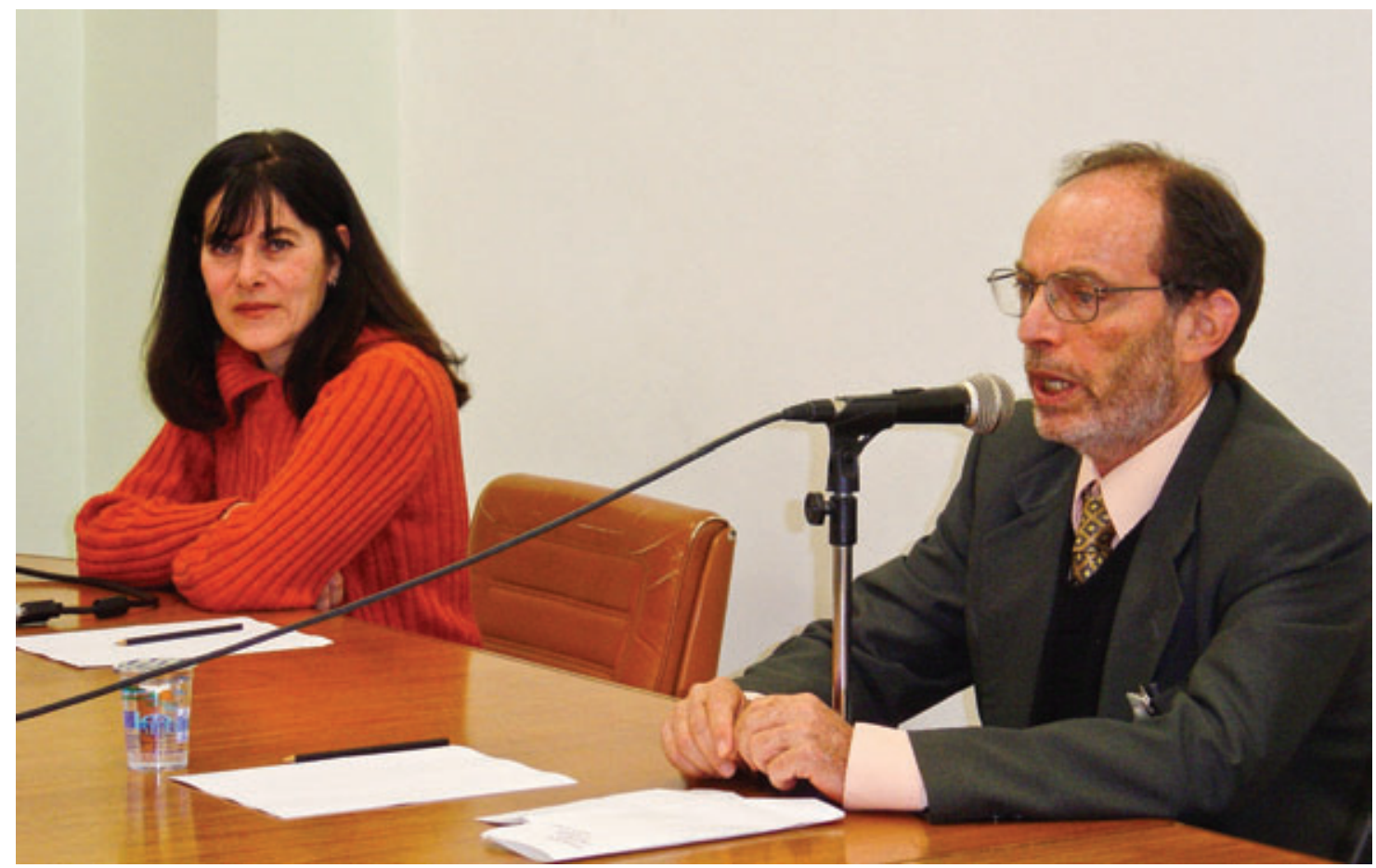

Mayana Zatz fez conferência em 2004; foi apresentada por Hernan Chaimovich, ex-pice-diretor do Instituto.

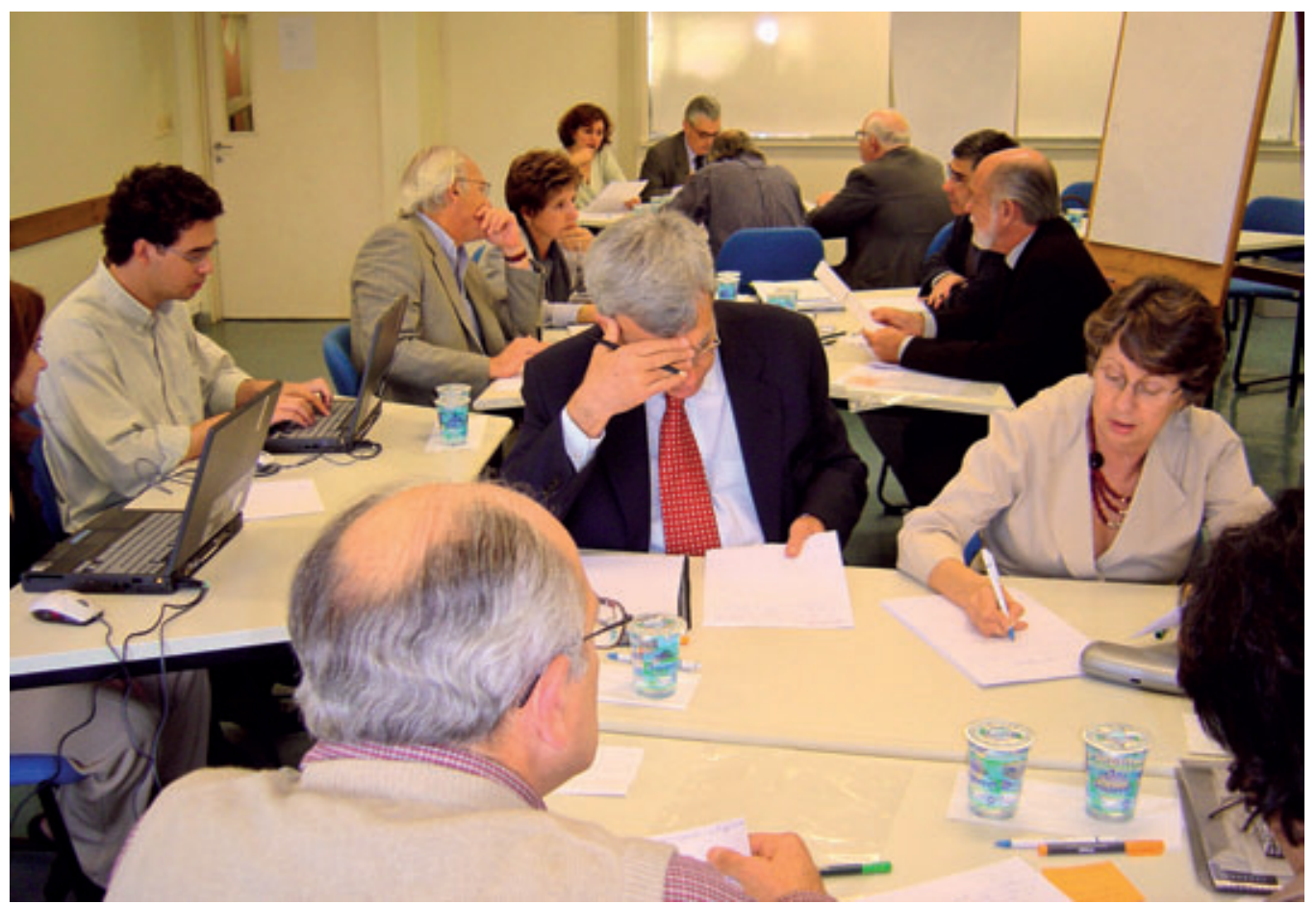

Em 2004 e 2005, uma equipe do IEA participou do Projeto Brasil 3 Tempos, do Governo Federal, traçando cenários prospectivos sobre o pais nas áreas institucional e internacional. 


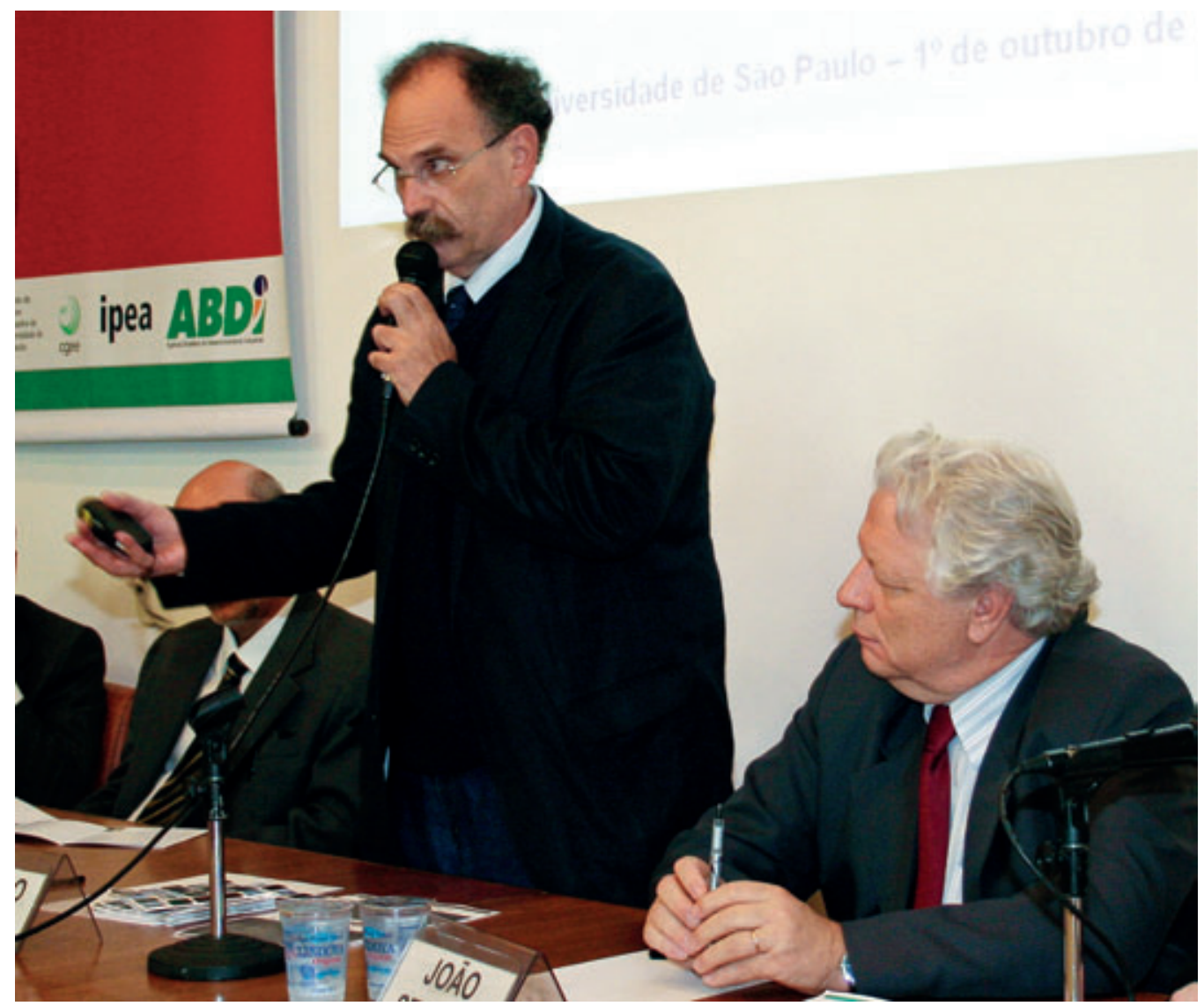

Glauco Arbix (à esq.), coordenador do Observatório da Inovação e Competitividade, e João Steiner, ex-diretor do IEA, no lançamento do projeto em 2007.

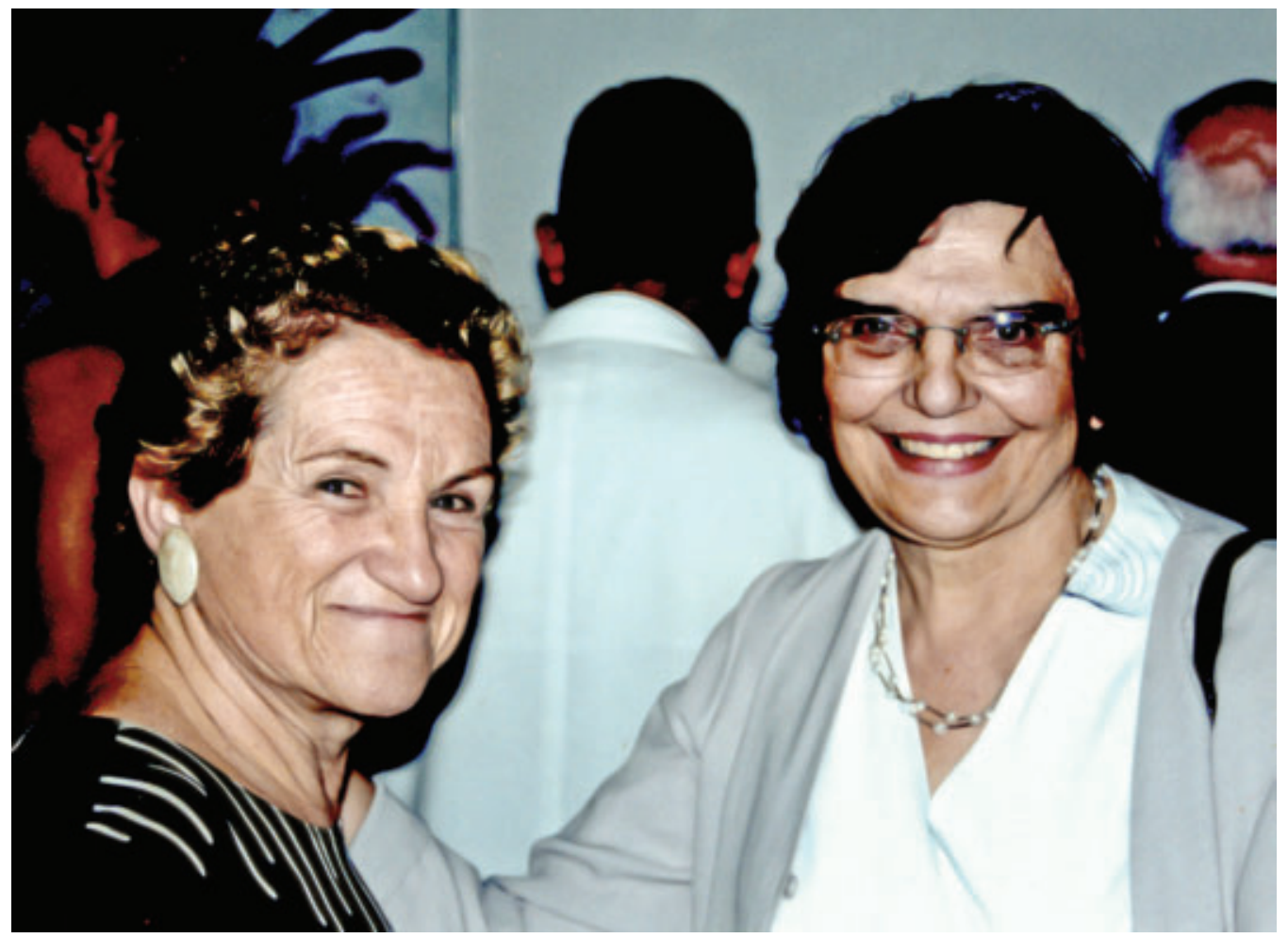

Lenina Pomeranz e Amélia Império Hamburger (1932-2011), ex-pesquisadoras visitantes. 


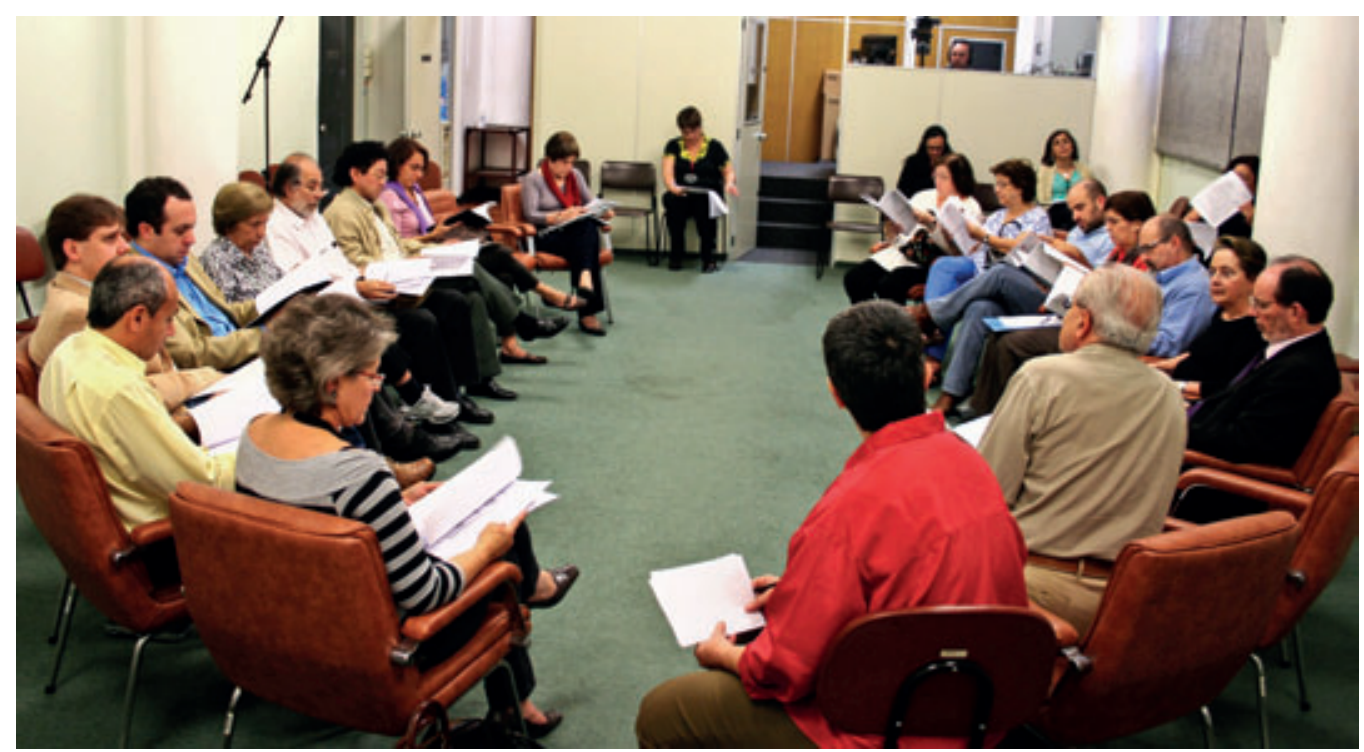

Reunião dos coordenadores de grupos de pesquisa em 2009.

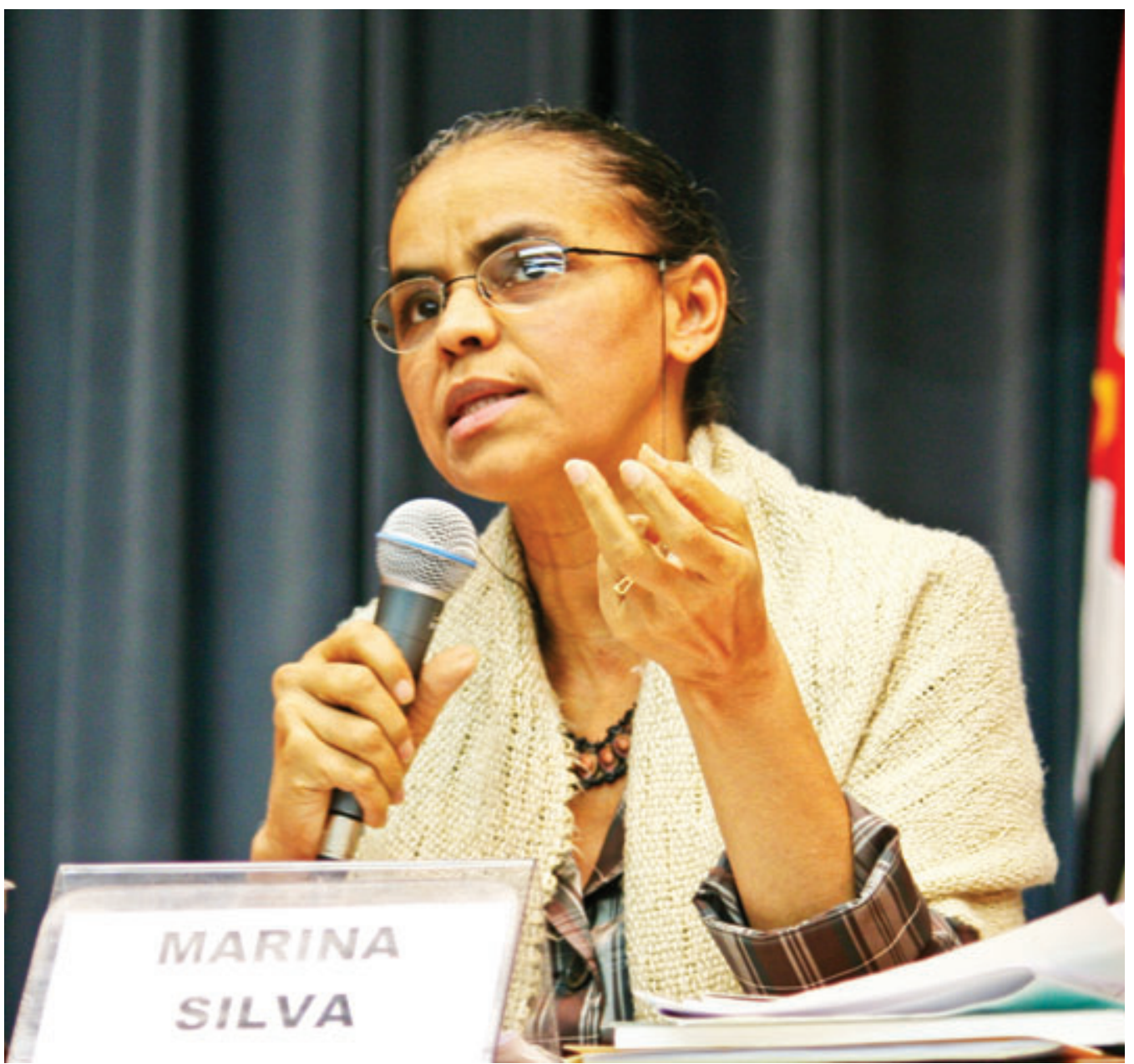

A então senadora e ex-ministra do Meio Ambiente Marina Silva foi conferencista convidada em 2009. 


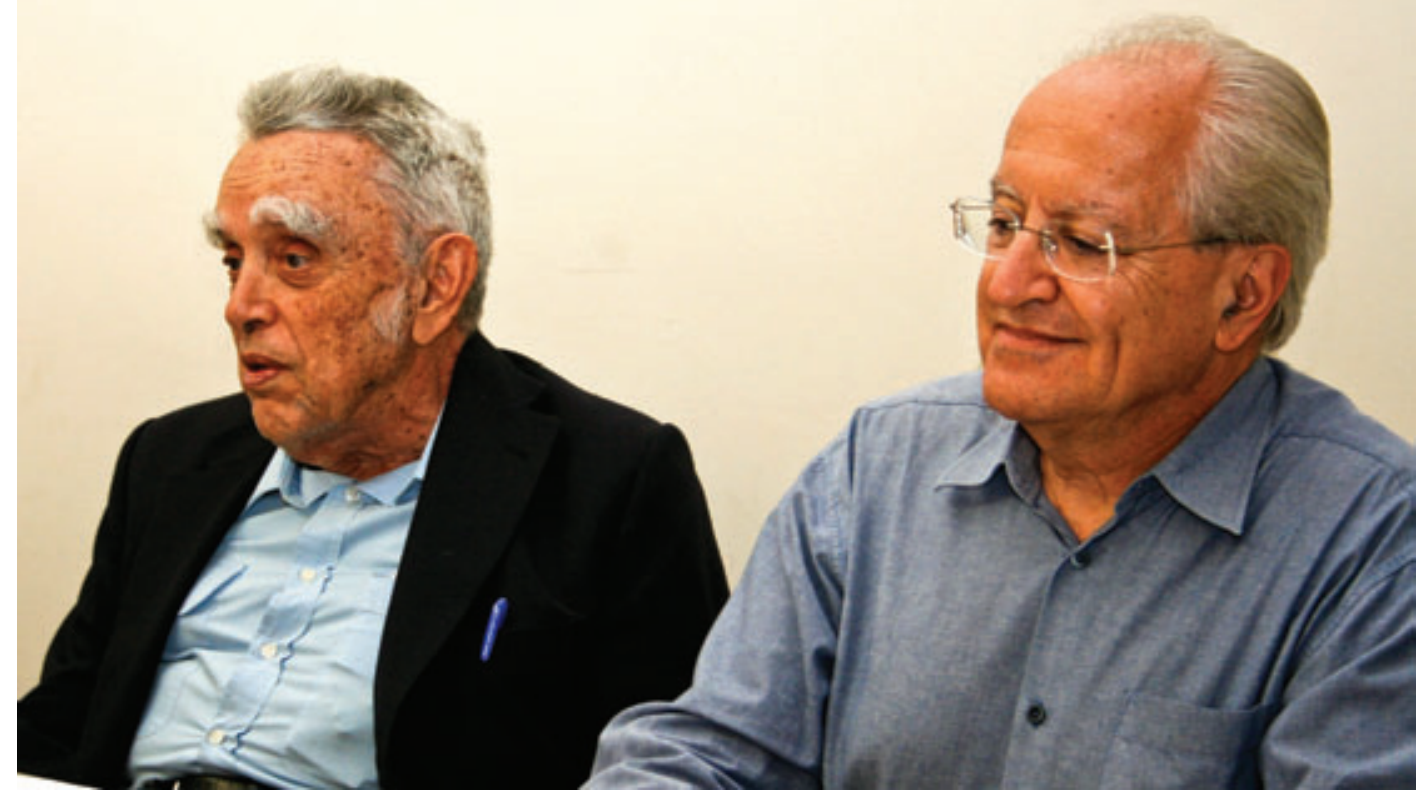

Paulo Nogueira-Neto, professor honorário e ex-professor visitante, e César Ades, atual diretor do IEA.

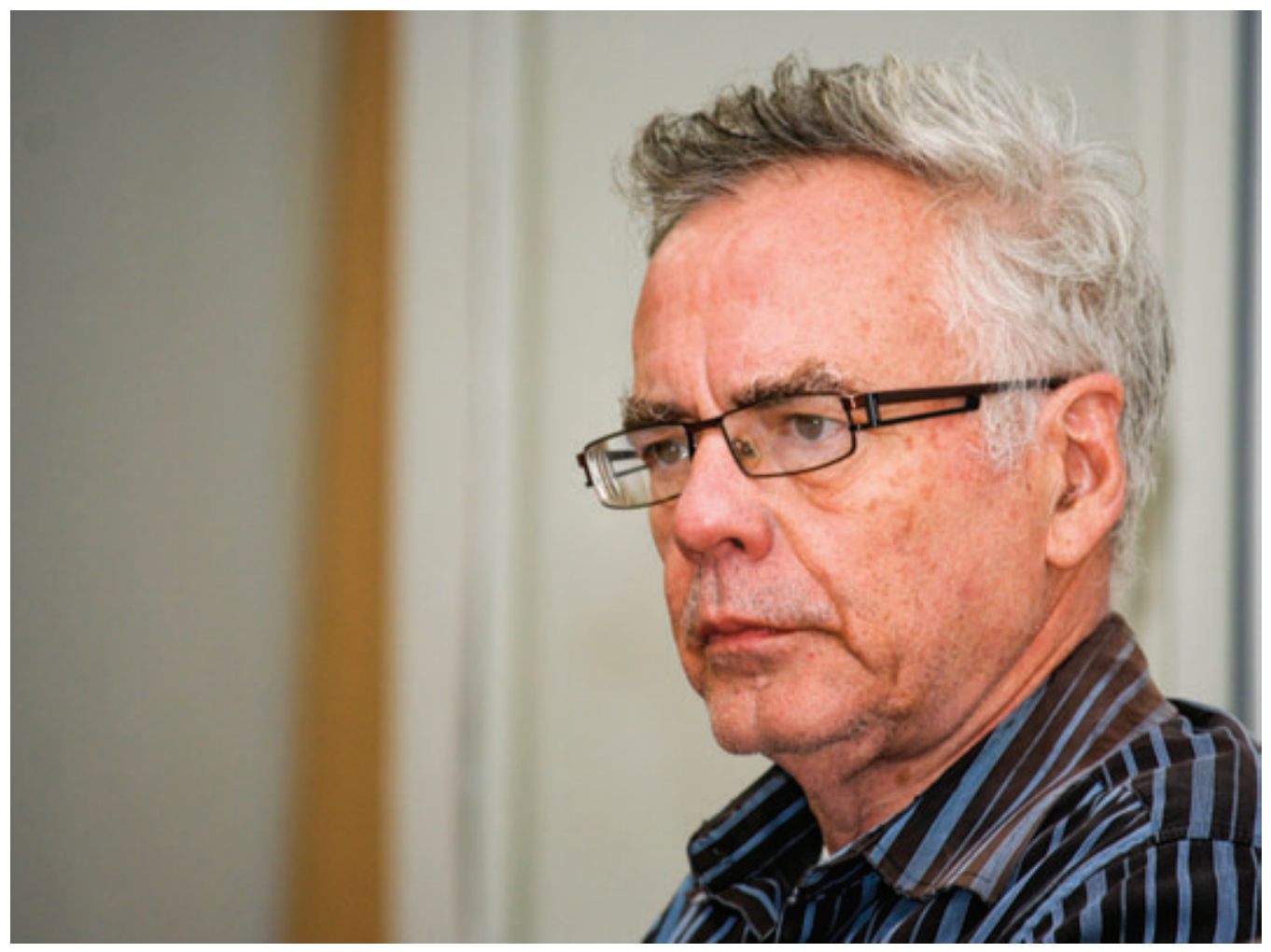

Robert Trivers foi um dos destaques da programação de eventos públicos em 2010. 


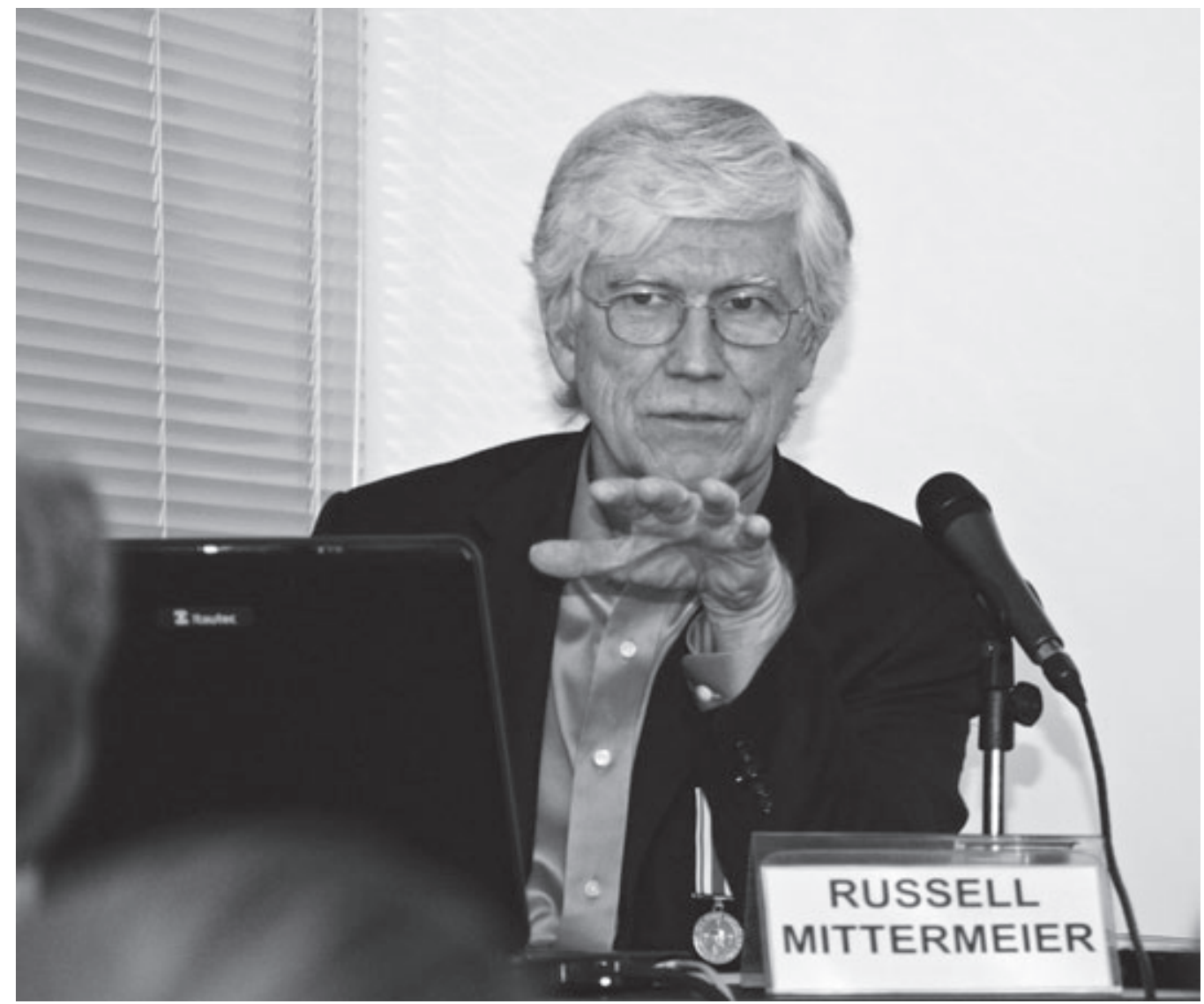

Russell Mittermeier fez conferência em 2011 a convite do Grupo de Pesquisa Amazônia em Transformação: História e Desafios.

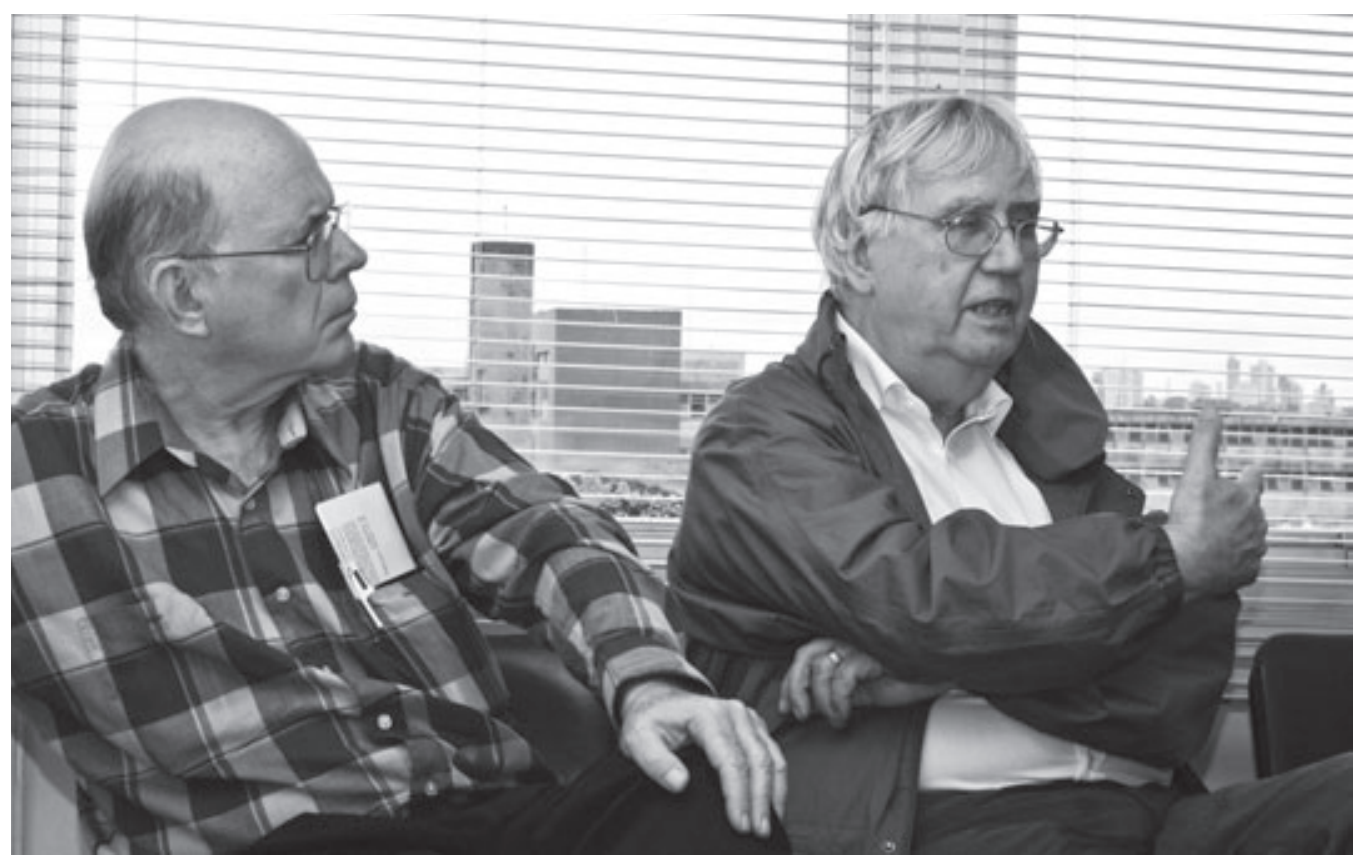

Eliezer Rabinovici, diretor do IEA de Jerusalém, Israel, e Peter Goddard, diretor do IEA de Princeton, EUA, durante visita ao Instituto em 2011. 


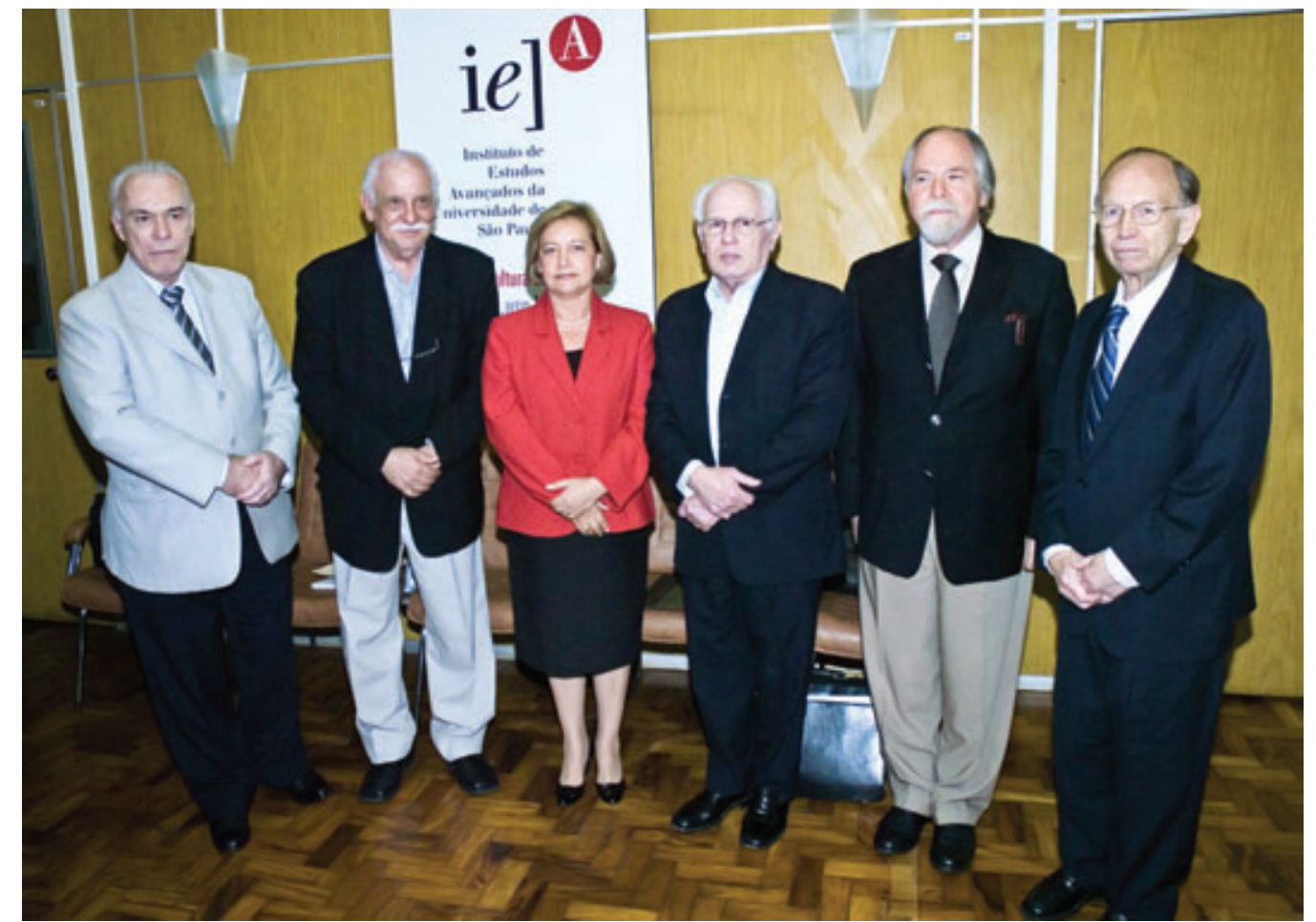

Em foto de 2008, a então reitora Suely Vilela na companbia de cinco ex-reitores (a partir da esq.): Flávio Fava de Moraes, Adolpho José Melfi, José Goldemberg, Jacques Marcovitch e Antônio Hélio Guerra.

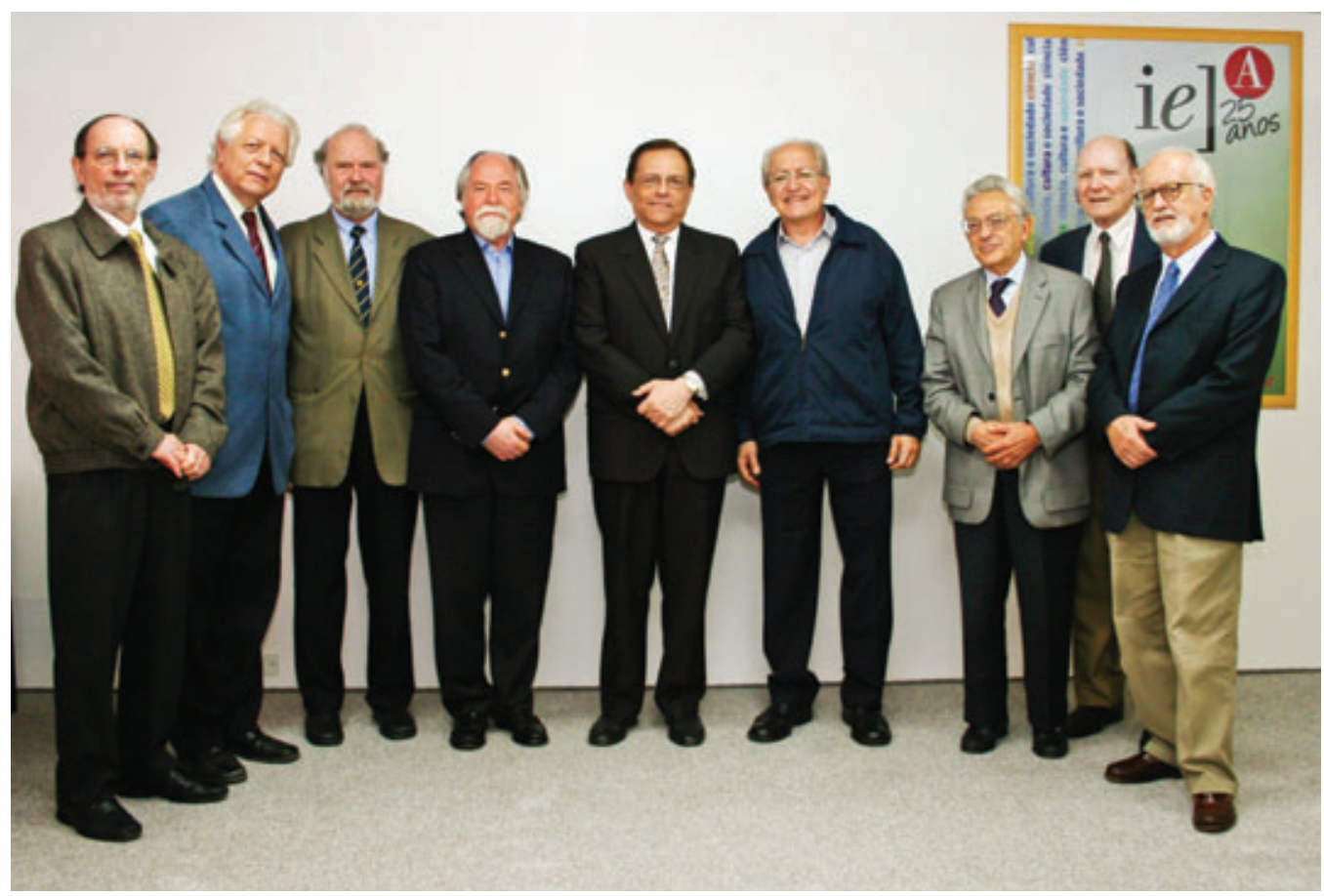

Em setembro de 2011, o reitor João Grandino Rodas participou de encontro com o diretor e ex-diretores do IEA; na foto (a partir da esq.): Hernan Chaimovich (ex-vice-diretor), João Steiner, Umberto Cordani, Jacques Marcovitch, João Grandino Rodas (reitor), César Ades (atual diretor), Alfredo Bosi, Gerhard Malnic e Carlos Guilherme Mota. 